Research article

Open Access

\title{
Multivariate Numerical Taxonomy of Mentha Species, Hybrids, Varieties and Cultivars
}

\author{
Broza Šarić-Kundalić * ${ }^{1}$, Silvia Fialová * ${ }^{2}$, Christoph DobeŠ ${ }^{1}$, \\ Silvester ÖLZANT ${ }^{1}$, Daniela TEKELOVÁ ${ }^{2}$, Daniel GRANČAI ${ }^{2}$, \\ Gottfried REZNICEK ${ }^{1}$, Johannes SAUKEL ${ }^{1}$
}

${ }^{1}$ Department of Pharmacognosy, University of Vienna, Althanstraße 14, 1090 Vienna, Austria.

2 Department of Pharmacognosy and Botany, Faculty of Pharmacy, Comenius University, Odbojarov 10, 83232 Bratislava, Slovakia.

*Corresponding author. E-mails: broza.saric@gmail.com (B. Šarić-Kundalić), fialova@fpharm.uniba.sk (S. Fialová)

Sci Pharm. 2009 77: 851-876

doi:10.3797/scipharm.0905-10

Published: October $29^{\text {th }} 2009$

Accepted: October $28^{\text {th }} 2009$

Received: $\quad$ May $15^{\text {th }} 2009$

This article is available from: http://dx.doi.org/10.3797/scipharm.0905-10

(c) Šarić-Kundalić et al.; licensee Österreichische Apotheker-Verlagsgesellschaft m. b. H., Vienna, Austria.

This is an Open Access article distributed under the terms of the Creative Commons Attribution License (http://creativecommons.org/licenses/by/3.0/), which permits unrestricted use, distribution, and reproduction in any medium, provided the original work is properly cited.

\section{Abstract}

A taxonomic study into the anatomical, morphological and phytochemical differentiation of the genus Mentha $L$ (Lamiaceae) in Bosnia \& Hercegovina and Slovakia is presented. Following a population-based approach and using hierarchical cluster analyses the following basic species and hybrids corresponding to exclusive branches, i.e. groups, in the constructed hierarchies were recognized: Mentha aquatica, M. spicata, M. arvensis, M. longifolia, M. rotundifolia, $M . \times$ piperita, $M . \times$ villosa, $M . \times$ verticillata, $M . \times$ gentillis, $M . \times$ gracilis and $M$. pulegium. These groups were independently found by separate analyses of the sampled anatomical and morphological variation. In contrast, these anatomically and morphologically defined species exhibited a high level of phytochemical polymorphism which was largely inconsistent with the hierarchical classification. Among the analysed characters, the inflorescence type, dentation of the leaf margin, hair density, the type of capitate glandular hairs, and the main containing compound in essential oil proved most useful for the discrimination of taxa. However, most of the observed traits were not exclusive to a particular species and only the combined consideration of traits revealed coherent taxonomic groups. Basic species and hybrids are described in detail based on the anatomical, morphological and phytochemical characters used for their definition. The performed cluster analysis finally supported hypotheses on the parentage of some of the studied hybrids. 


\section{Keywords}

Mentha $•$ Anatomy $・$ Morphology $•$ Essential oil $•$ Biostatistics

\section{Introduction}

Mints are herbaceous, perennial aromatic herbs that are cultivated for their essential oils used both for medicinal and aromatic purposes. It was noted that mints are mainly used to cure gastrointestinal disorders, but the spectrum of medical activities is broader [1]. The taxonomy of mints, genus Mentha from the Lamiaceae family, is a complex problem and several classifications varying in the number of recognized species have been proposed in the past [2]. Mentha is of worldwide distribution and comprises according to the latest taxonomic treatment [3] 18 species and additional 11 hybrids placed into the four sections Pulegium, Tubulosae, Eriodontes, and Mentha.

More then 3,000 names, from species to formae, have been published for the genus Mentha since Linné (1753). The systematics of section Mentha is especially difficult because of frequent hybridization occurring both in wild populations and in cultivation [4]. Outcrossing is favored by genodioecy and the taxonomy of this hybrid complex is complicated by concomitant polyploidy and stabilization of novel forms by ease of vegetative propagation [2]. Within section Mentha it has been suggested that the five basic species Mentha arvensis L., Mentha aquatica L., Mentha spicata L., Mentha longifolia (L.) Huds, and Mentha suaveolens Ehrh. have given rise to eleven naturally occurring and named hybrids [3]. However, $M$. spicata and possibly $M$. longifolia are also of hybrid origin and incongruence of nuclear and plastid DNA based phylogenies indicated that all species of this section may have experienced some extend of reticulate gene flow during their evolution [5].

The present literature [6] suggests a differentiation of section Mentha into the three basic lines, capitatae, spicatae, and verticillatae, based on inflorescence characters (Table 1). The line 'capitatae' includes all species with compact, head-like inflorescence; the type species is $M$. aquatica. The 'spicatae' species have a spike as shown by $M$. spicata, $M$. longifolia, and $M$. suaveolens. The third line is represented by $M$. arvensis having a inflorescence vertically partitioned into whorls.

Tab. 1. Classification of the section Mentha based on inflorescence characters

\begin{tabular}{|c|c|c|}
\hline 'Capitatae' & 'Spicatae' & 'Verticillatae' \\
\hline M. aquatica L. & M. $\times$ dumetorum Schultes & M. arvensis L. \\
\hline M. dahurica Fisch. ex. Benth & . M. Iongifolia (L.) L. & M. canadensis L. \\
\hline \multirow[t]{4}{*}{ M. japonica (Miq.) Makino } & $\begin{array}{l}\text { M. × maximilianea } \\
\text { F W Schultz }\end{array}$ & M. $\times$ carinthiaca Host \\
\hline & M. × piperita L. Huds. & M. × dalmatica Tausch \\
\hline & & $\begin{array}{l}\text { M. } \times \text { gracilis Sole } \\
\text { (syn. M. × gentilis Auct, non. L.) }\end{array}$ \\
\hline & $\begin{array}{l}\text { M. suaveolens Ehrh. } \\
\text { (syn. M. rotundifolia L.) } \\
\text { M. × villosa Huds. }\end{array}$ & $\begin{array}{l}\text { M. × smithiana R. Graham } \\
\text { M. × verticillata L. }\end{array}$ \\
\hline
\end{tabular}


However, alternatively mints were classified based on the dominant monoterpene compound prevailing in the essential oil reflected by three metabolic pathways (Table 2). Thus the production of linalool and linalylacetate is typical for the linalool pathway; menthol, menthone and menthofuran are constitutes of the menthol pathway; and carvon, dihydrocarvone and carveol, finally, characterize the carvon pathway [7,8]. These pathways are as examples represented by $M$. aquatica var. citrata; $M$. × piperita; and $M$. spicata, respectively.

Tab. 2. Classification of Mentha species according to main monoterpene compounds [8]
Menthol Pathway
M. aquatica L.
M. arvensis $L$.
M. canadensis L.
M. cervina $L$.
M. dahurica Fisch. ex. Benth.
M. diemenica Spreng.
M. $\times$ dumetorum Schultes
M. gattefossei Maire
M. × gracilis Sole
(syn. M. $\times$ gentilis auct non. L.)
M. grandiflora Benth.
M. japonica (Miq.) Makino
M. longifolia (L.) L.
M. longifolia subsp. typhoides (Briq.)
Harley
M. × maximilianea F.W.Schultz
M. × piperita $L$.
M. pulegium L.
M. repens (Hook. f.) Briq
$M$. requienii Benth.
M. satureoides $\mathrm{R}$. Br.
M. suaveolens Ehrh.
(syn. M. rotundifolia L.)
M. $\times$ verticillata $L$.
M. X villosa Huds.

Linalool Pathway

Carvon Pathway

M. × dalmatica Tausch

M. longifolia (L.) L.

M. × smithiana R. Graham

M. suaveolens Ehrh.

(syn. M. × rotundifolia L.)

M. spicata $L$.

M. × villosa Huds.

\section{Essential Oil Composition \\ Unknown \\ M. australis $\mathrm{R}$. $\mathrm{Br}$. \\ $M$. laxiflora Benth. \\ M. $\times$ carinthiaca Host}

M. aquatica var.

citrata (Ehrh.) Frensen.

M. longifolia (L.) L.

var. lavanduliodora ined.

M. × piperita var. citrata (Ehrh.)

M. × piperita (L.) Huds.

var. lavanduliodora ined.

Multiple features have been exploited in the past to describe the diversity of the genus Mentha including morphological [9-12], palynological [13], cytological [4], anatomical [14], phytochemical [14-16], and genetic [5, 17-18] evidence. These studies unravelled high degrees of variability of these features in section Mentha. Polymorphisms were particularly observed in hybrid populations which accrue because of subfertility compensated by 
vegetative propagation which conserves novel genotypes. However, high polymorphism in morphology and great diversity in essential oil composition embarrass the whole process of identification. Nevertheless, phytochemical studies proved useful to infer the parentage of hybrids. The composition of the essential oil was thereby characteristic for each mint and the relationships among mints could be deduced from the similarity of these patterns although the composition may vary during the year [16].

In scope of our research, we found that there exists a large diversity of mints in the area of Bosnia and Herzegovina, but that there is no recent taxonomical treatment of Mentha in this territory. Slovakia offers a similar mint diversity, which was more recently presented in respective domestic floras, but without detailed consideration of plant anatomy and phytochemistry $[19,20]$. Interestingly, there is in general a lack of proper anatomical descriptions (except M. × piperita) 21 despite high variation and differentiation of Mentha in these characters.

The complex evolutionary relationships including in particular extensive hybridization and polyploidization yet precluded the development of a consistent classification concept which is reflective of the true phylogenetic relationships among species. However, as has recently been shown for hybrid and parental species of section Mentha using DNA fingerprint data covering the whole genome, accessions from the studied taxa were grouped - except for $M$. spicata - in accordance with current classification based on morphological and cytological features [5]. These results indicate that despite complex evolutionary and genealogical relationships, distinct taxonomic units clearly do exist in section Mentha. In referring to this evidence, we aim in this study to

(i) classify section Mentha within Bosnia-Herzegovina and Slovakia based on morphological, phytochemical and the particularly underexplored anatomical features and a sample representative of the morphological variability in these countries. Groups obtained by cluster analyses subsequently will be

(ii) taxonomically identified by comparison to published classifications, and

(iii) characters discriminative for those groups extracted and discussed. By this approach we aim to provide a valid and practical concept for the identification of Mentha species in Bosnia-Herzegovina and Slovakia and a guideline for the respective usability of morphological, phytochemical and anatomical characters in this taxonomically complex genus.

\section{Experimental}

\section{Plant material}

Thirty-three Mentha populations were collected from 17 localities in Bosnia and Herzegovina (B \& H), Southern Europe, and Slovakia, Central Europe. In order to cover a representative part of the variability of the genus present in these geographic areas, populations from all three basic morphotypes of section Mentha (capitatae, spicatae and verticillatae) were sampled. Groups of individuals obtained in cluster analyses based on morphological, phytochemical as well as anatomical characters as performed in this study were subsequently taxonomically compared to described species by means of identification keys [3, 19-22] (Table 3). Herbarium vouchers of the studied populations were deposited in the herbarium of the Department of Pharmacognosy, Vienna (WUP). 
Tab. 3. Plant material studied; Taxonomic identifications follow [2]. Collectors: Broza Šarić-Kundalić (B. Š.-K.), Silvia Fialová (S. F.)

\begin{tabular}{|c|c|c|}
\hline Taxon & Collection History & Collection Site \\
\hline M. aquatica L. & 02.10.07, S. F. & $\begin{array}{l}\text { Holombecká dolina, Modra, } \\
\text { Slovakia }\end{array}$ \\
\hline \multirow{2}{*}{ M. spicata L. } & $\begin{array}{l}\text { 24.05.07, B. Š.-K. } \\
\text { 21.06.07, B. Š.-K. }\end{array}$ & $\begin{array}{l}\text { Maoča, Zavidovići, B \& H } \\
\text { Crnjevo, Banovići, B \& H }\end{array}$ \\
\hline & 01.07.07, S. F. ex cult. & $\begin{array}{l}\text { "The Garden of Medical Plants", } \\
\text { "Bratislava, Slovakia }\end{array}$ \\
\hline var. crispa (Benth.) Danert & 16.07.07, S. F. ex cult. & $\begin{array}{l}\text { "The Garden of Medical Plants", } \\
\text { "Bratislava, Slovakia }\end{array}$ \\
\hline M. arvensis L. & 16.07.08, S. F. & Revište, Žarnovica, Slovakia \\
\hline \multirow[t]{2}{*}{ M. longifolia ssp. longifolia L. } & $\begin{array}{l}\text { 24.07.07, B. Š.-K. } \\
\text { 10.07.07, B. Š.-K. } \\
\text { 08.07.07, B. Š.-K. } \\
\text { 21.07.06, B. Š.-K. } \\
\text { 24.07.07, B. Š.-K. }\end{array}$ & $\begin{array}{l}\text { Bistričak, } 25 \text { km from Zenica, B \& H } \\
\text { Tešanj, B \& H } \\
\text { Maoča, Zavidovići, B \& H } \\
\text { Ilinčica, Tuzla, B \& H } \\
\text { Smetovi, } 15 \text { km from Zenica, B \& H }\end{array}$ \\
\hline & 20.06.07, S. F. ex cult. & $\begin{array}{l}\text { "The Garden of Medical Plants", } \\
\text { "Bratislava, Slovakia }\end{array}$ \\
\hline \multirow[b]{2}{*}{ var. lavanduliodora s.I. } & 24.05.07, B. Š.-K. & Maoča, Zavidovići, B \& H \\
\hline & 20.06.07, S. F. ex cult. & $\begin{array}{l}\text { "The Garden of Medical Plants", } \\
\text { Bratislava, Slovakia }\end{array}$ \\
\hline ssp. typhoides (Briq.) Harley & 22.07.07, B. Š.-K. & Kamberovića polje, Zenica, B \& H \\
\hline M. rotundifolia (L.) Huds. & 24.05.07, B. Š.-K. & Maoča, Zavidovići, B \& H \\
\hline $\begin{array}{l}\text { M. × piperita (L.) Huds. cv. } \\
\text { 'Perpeta' }\end{array}$ & 16.07.07, S. F. ex cult. & $\begin{array}{l}\text { "The Garden of Medical Plants", } \\
\text { "Bratislava, Slovakia }\end{array}$ \\
\hline var. lavanduliodora s.I. & 24.05.07, B. Š.-K. & Maoča, Zavidovići, B \& H \\
\hline \multirow[t]{2}{*}{ M. $\times$ villosa Huds. } & $\begin{array}{l}\text { 18.07.07, B. Š.-K. } \\
\text { 15.07.07, B. Š.-K. } \\
\text { 21.07.06, B. Š.-K. }\end{array}$ & $\begin{array}{l}\text { Breštica, Banovići, B \& H } \\
\text { Plave vode, Travnik, B \& H } \\
\text { Maoča, Zavidovići, B \& H }\end{array}$ \\
\hline & 01.07.07, S. F. ex cult. & $\begin{array}{l}\text { "The Garden of Medical Plants", } \\
\text { "Bratislava, Slovakia }\end{array}$ \\
\hline cv. 'Snežna' & 01.07.07, S. F. ex cult. & $\begin{array}{l}\text { "The Garden of Medical Plants", } \\
\text { Bratislava, Slovakia }\end{array}$ \\
\hline M. $\times$ verticillata $\mathrm{L}$. & 24.07.07, B. Š.-K. & Bistričak, 25 km from Zenica, B \& H \\
\hline \multirow[b]{2}{*}{ M. $\times$ gentilis auct non. L. } & $\begin{array}{l}\text { 18.07.07, B. Š.-K. } \\
\text { 20.07.07, B. Š.-K. }\end{array}$ & $\begin{array}{l}\text { Jezero, Banovići, B \& H } \\
\text { Maoča, Zavidovići, B \& H }\end{array}$ \\
\hline & $\begin{array}{l}\text { 18.07.07, B. Š.-K. } \\
\text { 21.07.07, B. Š.-K. } \\
\text { 16.07.07, B. Š.-K. }\end{array}$ & $\begin{array}{l}\text { Treštenica, Banovići, B \& H } \\
\text { Crnjevo, Banovići, B \& H } \\
\text { Seona, Banovići, B \& H }\end{array}$ \\
\hline M. $\times$ gracilis Sole & $\begin{array}{l}\text { 18.07.07, B. Š.-K. } \\
\text { 25.07.07, B. Š.-K. }\end{array}$ & $\begin{array}{l}\text { Gradina, Banovići, B \& H } \\
\text { Hadžići, Sarajevo, B \& H }\end{array}$ \\
\hline Mentha pulegium L. & $\begin{array}{l}\text { 24.07.07, B. Š.-K. } \\
\text { 08.07.07, B. Š.-K. }\end{array}$ & $\begin{array}{l}\text { Bistričak, } 25 \text { km from Zenica, B \& H } \\
\text { Maoča, Zavidovići, B \& H }\end{array}$ \\
\hline
\end{tabular}




\section{Morphological, phytochemical and anatomical analyses}

The collected plant material was analysed for its morphological, phytochemical and anatomical properties applying morphometry and quantitative anatomy, light microscopy, scanning electron microscopy, and gas chromatography-mass spectrometry, respectively. Depending on the collected properties one to thirty individuals per population were analysed for each of the three created datasets.

\section{Morphometry}

The following morphological leaf characters were used for biometric analysis: length and median width of leaf blade, width of upper part (measured at 1/8 of the length of the leaf from the top of the leaf blade) and basal part of the leaf blade (measured at 1/8 of the length of the leaf from the base of the leaf blade), length of petiole (Figure 1, Table 4). The shape of leaves including the leaf margin (i.e. type of denticulation) was drawn from light microscopic preparations. For standardization the leaf pair fourth below the basal node of the inflorescence was used [23].

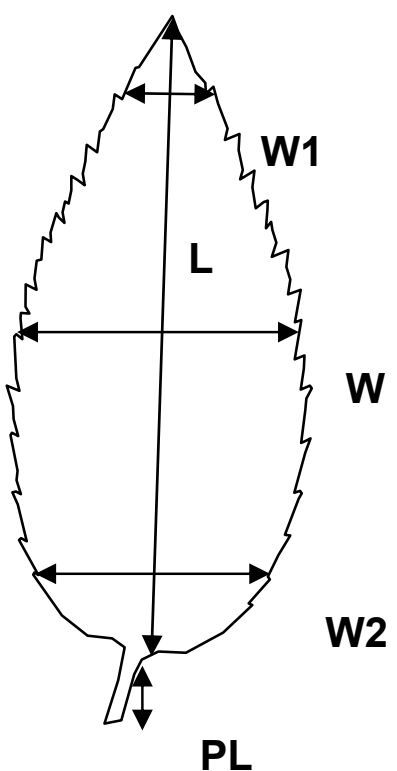

Fig. 1. L length of leaf blade; $W$ median width of leaf blade, W1 width of upper part of the leaf blade; W2 width of basal part of the leaf blade; PL length of petiole

Light microscopy (LM) and quantitative anatomy

Anatomical analyses were carried out using a Nikon Optiphot-2 and a Leica DME microscope equipped with a Leica EC3 Digital Camera. Leafs were placed on a glass slide, embedded in few drops of $60 \%$ chloralhydrate and shortly gently boiled in order to clear the samples.

\section{Scanning electron microscopy (SEM)}

Dried leaves were coated with gold using an Edwards Scancoat SIX sputter-coater and subsequently examined in a Phillips XL 30 ESEM microscope using the HiVac modus (i.e. secondary electron detector, acceleration voltage $15 \mathrm{Kv}$ ) [24]. 
Anatomical features (Table 4) were analysed on the lower surface of the leaf. The type of stomata, epidermal cells, glandular trichomes and non glandular trichomes as well as trichome density were recorded and the diameter of the head of peltate and capitate glandular trichomes measured. For each of these qualitative and quantitative characters at least 30 observations per population were made. The same leaf pair studied morphologically was also used for anatomical analyses.

Gas Chromatography-Mass Spectrometry (GC-MS)

For GC-MS a Column Zebron capillary ZB-WAX $(0,25 \mu \mathrm{m}$ film thickness, $60 \mathrm{~m}$ length $\mathrm{x}$ $0,25 \mathrm{~mm}$ ID.) was used, $50 \mathrm{mg}$ dry leaf sample were extracted in $500 \mu \mathrm{l}$ dichloromethane and treated by ultrasonification for 10 minutes at room temperature. $1 \mu$ l aliquots were analyzed [23].

Tab. 4. Summary of morphological, anatomical and phytochemical characters studied ${ }^{a}$

\begin{tabular}{|c|c|c|}
\hline $\begin{array}{l}\text { Morphological } \\
\text { Characters }\end{array}$ & Anatomical Characters & Phytochemical Characters \\
\hline $\begin{array}{l}\text { length of leaf blade } \\
\text { median width of leaf } \\
\text { blade } \\
\text { width of upper part of the } \\
\text { leaf blade } \\
\text { width of basal part of the } \\
\text { leaf blade } \\
\text { length of petiole } \\
\text { leaf margin denticulation } \\
\text { (type of the denticles: } \\
\text { Type A-D) } \\
\text { inflorescence } \\
\text { ('capitatae'-Type A, } \\
\text { 'spicatae'-Type B, } \\
\text { 'verticillatae'-Type C) }\end{array}$ & $\begin{array}{l}\text { epidermal cells } \\
\text { (uniform) } \\
\text { stomata } \\
\text { (uniform) } \\
\text { type of glandular } \\
\text { trichomes (Type A-C) } \\
\text { type of non glandular } \\
\text { trichomes (Type A-C) } \\
\text { hair density (Type A-C) } \\
\text { width of the head of } \\
\text { capitate glandular } \\
\text { trichomes } \\
\text { width of the head of } \\
\text { peltate glandular } \\
\text { trichomes }\end{array}$ & $\begin{array}{l}\text { OCTANOL (3-octanol, } \\
\text { 3-octanone, 3-octanylacetate) } \\
\text { CARVONE (carvacrol, carvone, } \\
\text { dihydrocarveol, neodihydro- } \\
\text { carveol, trans-carveol, cis- } \\
\text { dihydrocarvone) } \\
\text { elemol } \\
\text { LINALOOL (citronellylacetate, } \\
\text { linalool, linalylacetate) } \\
\text { pulegone } \\
\text { TERPINENE (a-terpinene, } \\
\text { a-terpineol, y-terpinene, terpineol) }\end{array}$ \\
\hline
\end{tabular}


In the GC-MS analysis one plant from each population was investigated. In case of taxa represented in the data with only one population two individuals per population were analysed. The received peaks were identified using the 'SZTERP' database provided by 'Shimatsu Corporation'. Peaks were standardized by dividing the single individual peak area by the sum of the area of all 60 peaks identified. In the first cluster analysis only standardized compounds with a relative peak area of at least $15 \%$ were considered. In the second cluster analysis some compounds belonging to the chemotypes mentioned in Table 4 were pooled together. For example, carvone, carvacrol, dihydrocarveol, neodihydrocarveol, trans-carveol and cis-dihydrocarvone belonging to the carvone chemotype were pooled in the CARVONE group. These groups are presented in capital letters together with the respective chemical compounds included in Table 4. The second cluster analysis was performed because some compounds, (e.g. carvone and its derivate cis-dihydrocarvone) were recognized by the cluster analysis as two totally different compounds. As a consequence, these and similar compounds, belonged to different groups.

\section{Statistical data analysis}

Cluster analyses were performed using the Ward algorithm. Ward (1963) proposed a clustering method trying to form partitions $P_{n}, P_{n-1, \ldots,} P_{1}$ in a manner that minimizes the loss of information associated with each grouping, and to quantify that loss of information in a form that is readily interpretable. At each step in the analysis, the union of every possible cluster pair is considered and the two clusters, whose fusion results in minimum increase in loss of information, are eventually combined. Information loss is defined by Ward in terms of an error sum-of-squares criterion (ESS) and the use of squared Euclidean distance [distance $\left.(x, y)=\Sigma_{i}\left(x_{i}-y_{i}\right)^{2}\right]$. In general, this method is regarded as very efficiently, however, it tends to create clusters of more or less equal size, if possible. For our computations we are using the self-designed "Pharmacognostic Program Package" [25-27].

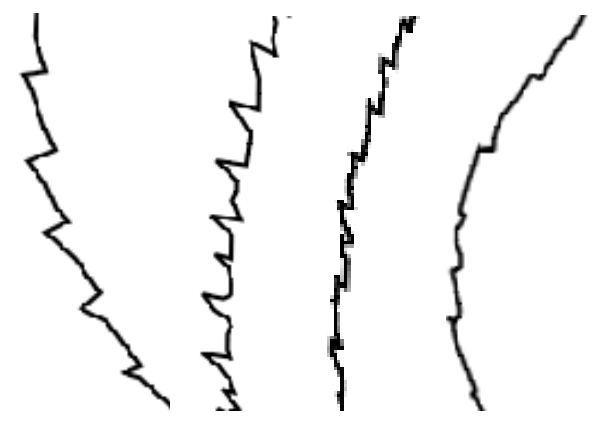

Fig. 2. Types of leaf margin, left to right: $M . \times$ villosa (Type A), M. longifolia (Type B), M. × verticillata (Type C), M. aquatica (Type D)

\section{Results and Discussion}

A summary of the results of the morphology, anatomy and phytochemistry of the investigated 33 Mentha populations analyzed by means of morphometry, light microscopy, quantitative anatomy, scanning electron microscopy and gas chromatography-mass spectrometry is provided in Table 5. Quantitative continuous characters as length of leaf blade, median width of leaf blade, width of upper part of the leaf blade, width of basal part 

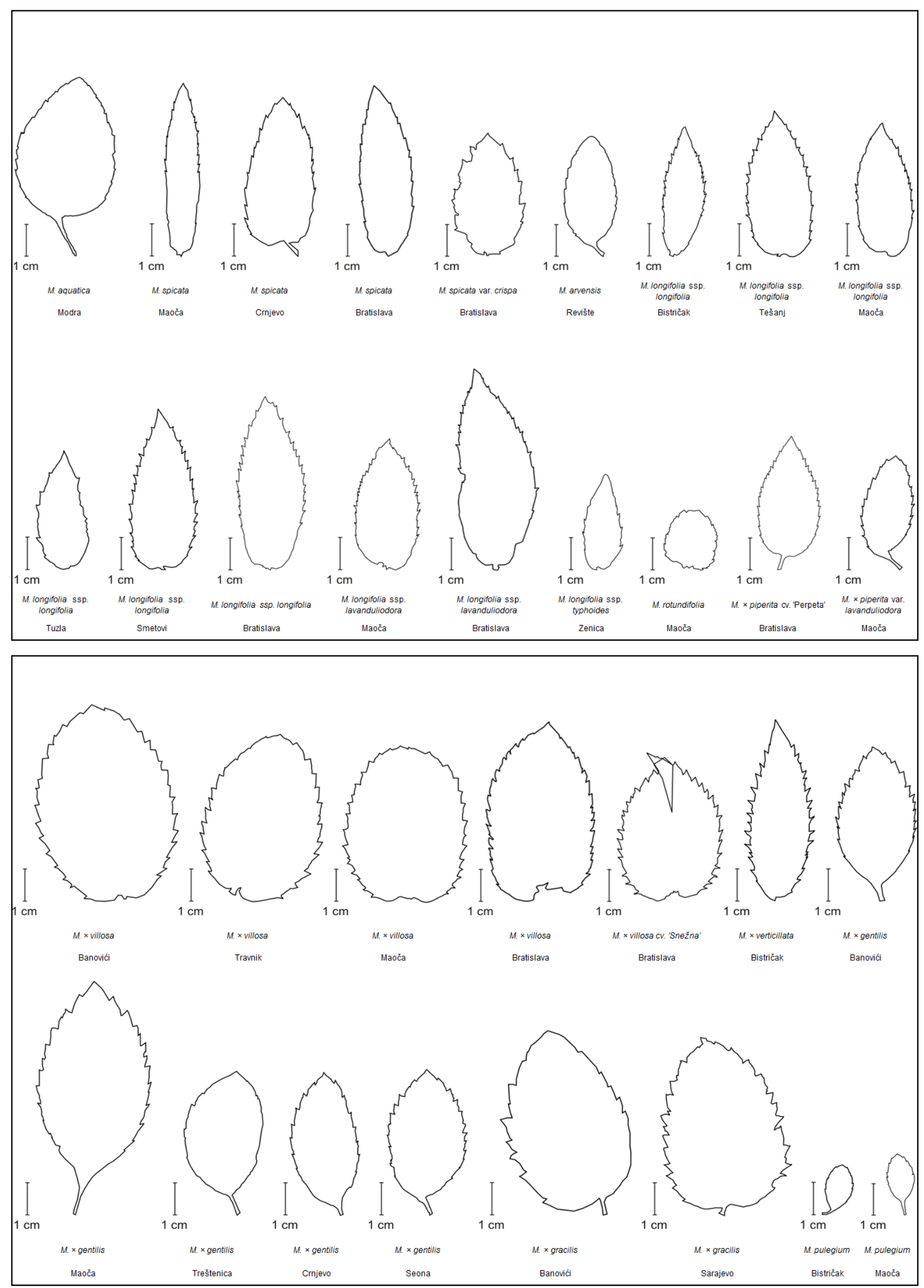

Fig. 3. Outline drawings of representative leafs from all investigated populations 
of the leaf blade, and length of petiole are given as the range measured in the individual populations. Qualitative and discrete characters as type of inflorescence, leaf margin denticulation (denticles), stomata and epidermal cells as well as type and density of glandular and non-glandular hairs were categorized into classes as follows. Classes were used as character states in the anatomical and morphological analyses of the studied material. Three inflorescence types 'capitatae', Type A; 'spicatae', Type B; and 'verticillatae', Type $\mathrm{C}$ as well as four different forms of leaf margin (i.e. types of the denticles) could be distinguished in the studied material. The first type is characterized by forward serrated denticles sticking out widely (Figure 2) as typically observed in $M$. $\times$ villosa (Type A). The second type is similar to Type A, but with smaller and more closely arranged denticles (Figure 2). The typical species for this group is M. longifolia (Type B). The third type is defined by having forward serrated leafs with denticles directed towards the leaf apex (Figure 2) as represented by $M . \times$ verticillata (Type $C$ ). The forth group, finally, is similar to Type $C$, but with smaller and more widely arranged denticles (Figure 2) as in M. aquatica (Type D).

Regarding the outline drawings of leaves, on the one hand the number of plants analysed for each population could be reduced to one because populations exhibited merely little variation in leaf form. The drawings presented in Figure 3, on the other hand, reflect the observed differences in leaf form among the investigated populations.

Epidermal cells were of the sinuous type, i.e. wavy cell walls, and stomata were diacytic. These features were observed only on the abaxial surface of leaves and were invariable for all mints (Figure 4).
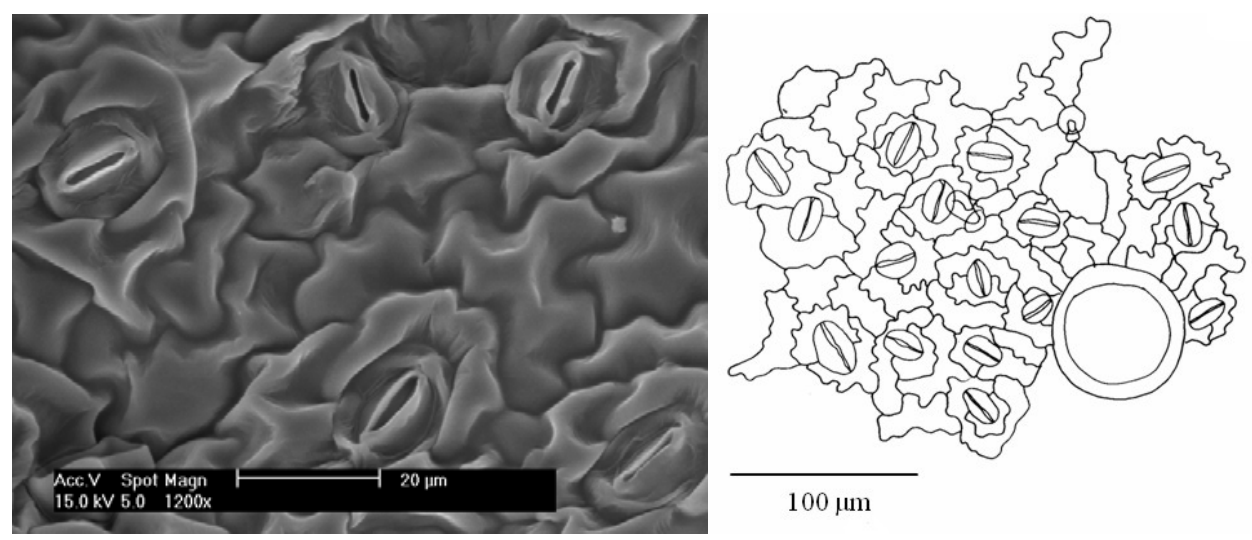

Fig. 4. Epidermal cells and stomata of the abaxial leaf surface.e.g. M. pulegium (Maoča, left) and M. × piperita cv. 'Perpeta' (Bratislava, right)

Hair cover consisted of non-glandular and glandular hair types observed on the upper and lower leaf surface. The non-glandular hairs were unicellular or multicellular, some of which had cuticular micropapillae, and referred to two types of hairs: unbranched (Figure 5) and dendroid hairs (Figure 6). Unbranched trichomes were found on both surfaces of the leaf of almost all studied mints. In contrast, dendroid trichomes were observed on the abaxial leaf surface of few species only. These mints can accordingly be discriminated from all other species by possession of dendroid hairs. Based on the presence of the dendroid trichomes, the studied species were classified into 3 groups: Type A - missing, Type B - 
scarce (rare) and Type $\mathrm{C}$-numerous (plenty). Non-glandular hair density varied considerably among species. Consequently, three density classes, scarse (Figure 7), medium (Figure 8) and dense (Figure 9), were defined to record the non-glandular hair cover of mints.
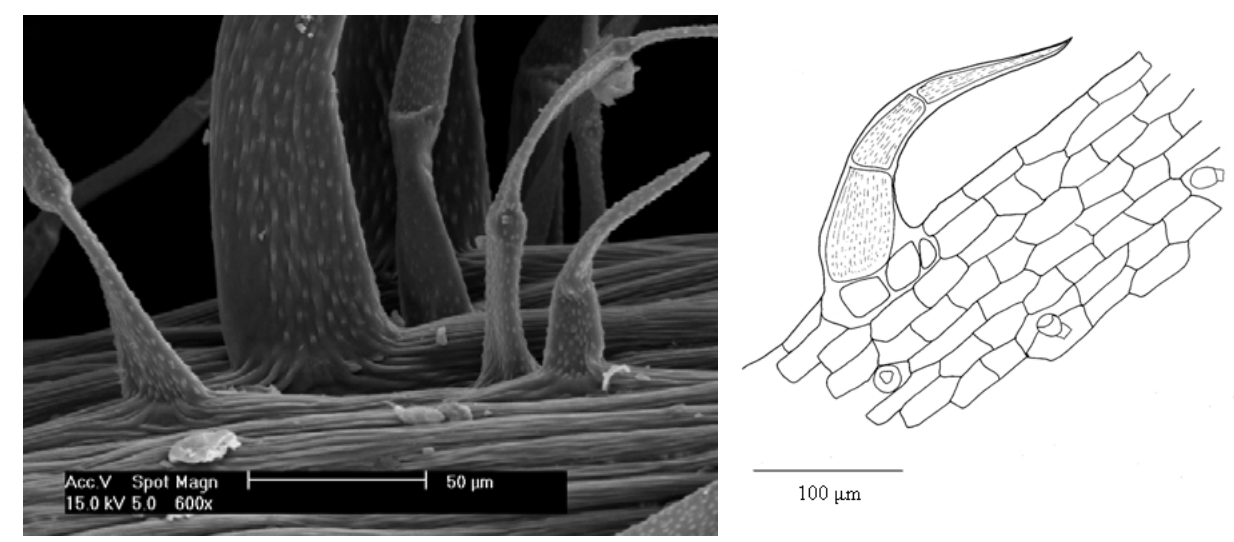

Fig. 5. Unbranched hairs on veins of the abaxial leaf surface: M. longifolia ssp. typhoides (Kamberovića polje, left) and M. aquatica (Bratislava, right)
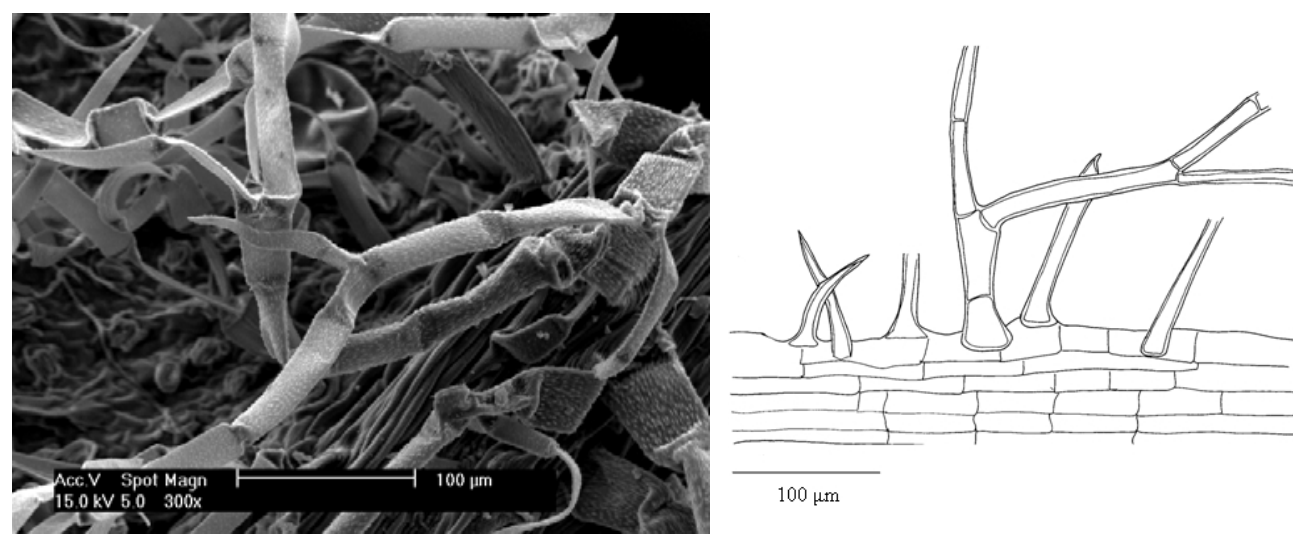

Fig. 6. Dendroid hairs on veins of the abaxial leaf surface: $M$. spicata var. crispa (Bratislava, left) and M. longifolia ssp. longifolia (Bratislava, right)

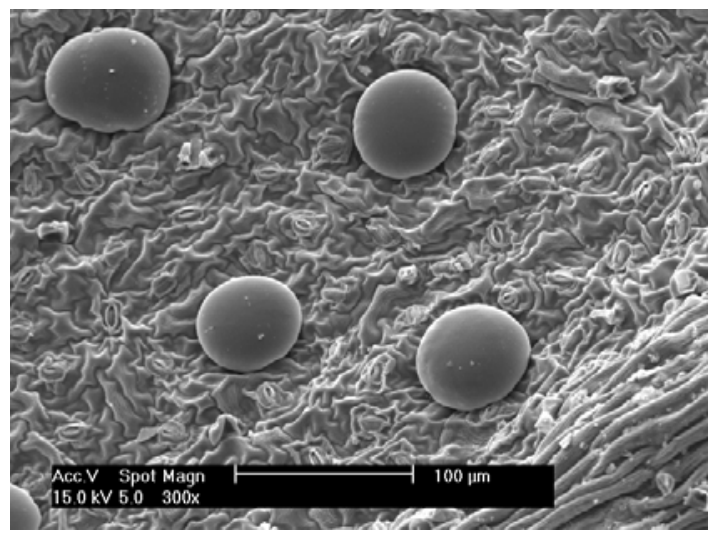

Fig. 7. Non-glandular hairs missing (Type A): abaxial surface of $M . \times$ piperita cv. 'Perpeta' leaves (Bratislava) 


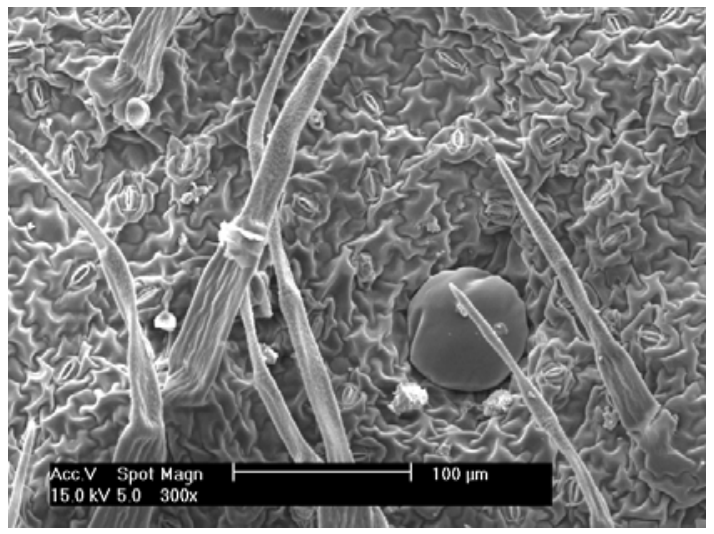

Fig. 8. Medium non-glandular hair density (Type B): abaxial surface of M. pulegium leaves (Bistričak)

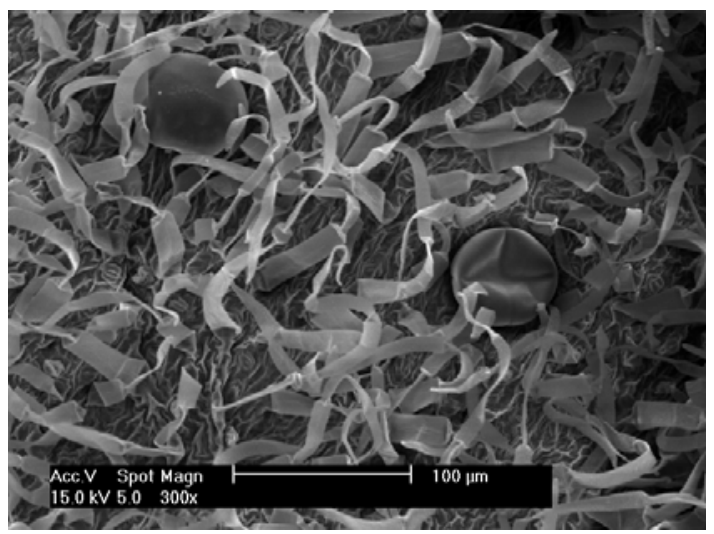

Fig. 9. Dense non-glandular hair cover (Type C): abaxial surface of M. longifolia ssp. longifolia leaves (Smetovi)

Two main types of capitate glandular trichomes could be distinguished (Fig. 10): (i) small glandular trichomes bearing a single secretory head cell, (ii) large peltate glandular trichomes (Fig. 11) composed of 8-12 secretory cells arranged in a single circle, subtended by a short monocellular stalk and a basal cell [28]. The peltate and capitate trichomes in addition differed from each other in their frequency of occurrence and secretory mode.
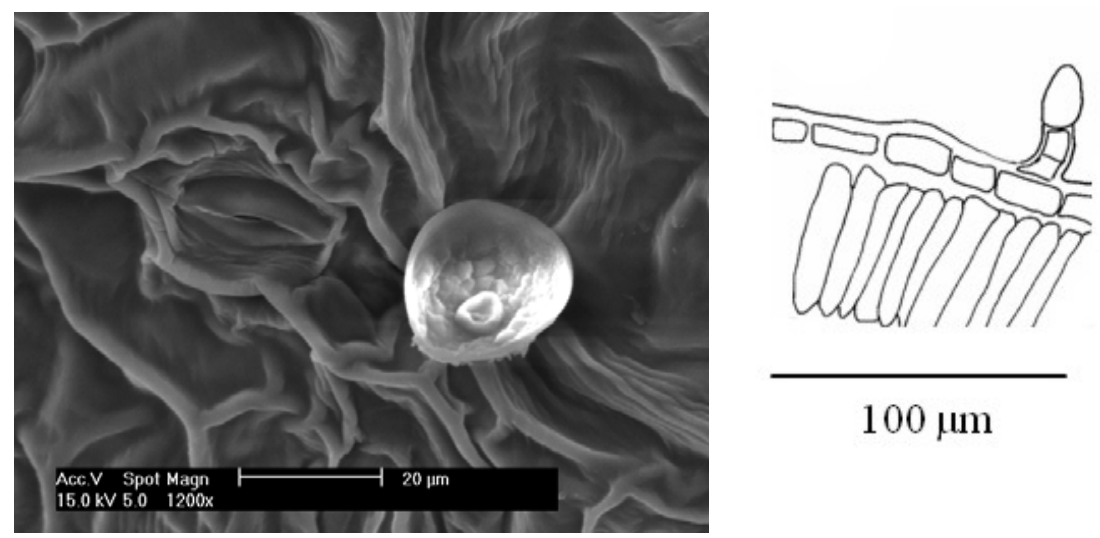

$100 \mu \mathrm{m}$

Fig. 10. Capitate glandular trichome: M. × piperita var. lavanduliodora (Maoča, left) and M. longifolia ssp. longifolia (Baratislava, right) 

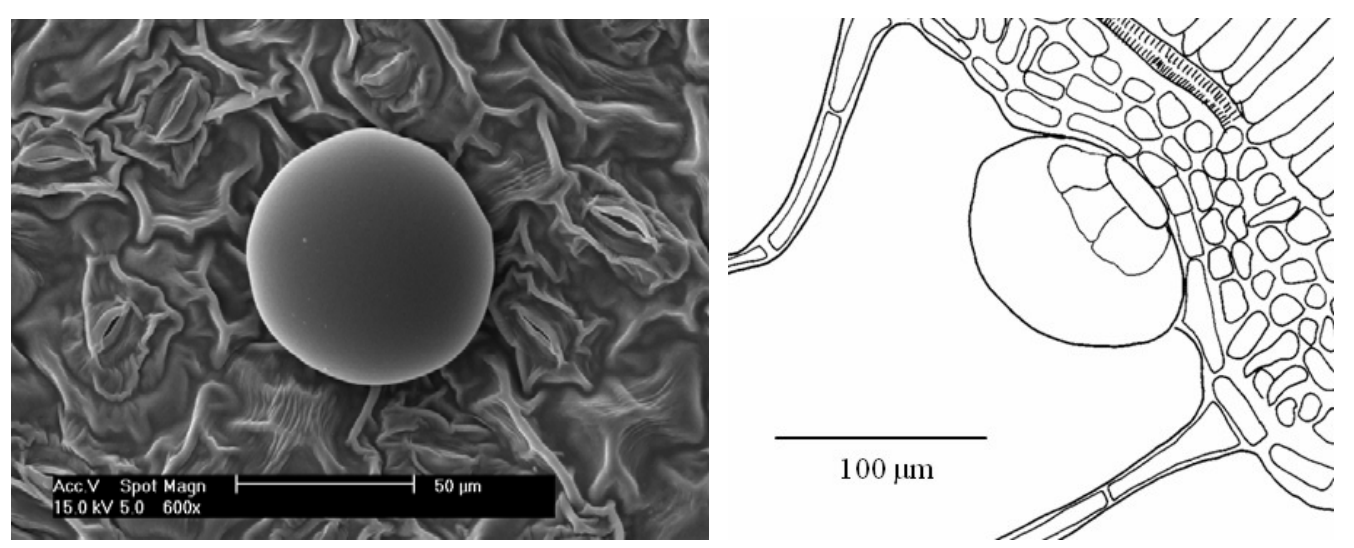

Fig. 11. Peltate glandular trichome: M. × piperita var. lavanduliodora (Maoča, left) and M. $x$ villosa (Bratislava, right)

Capitate glandular trichomes were of three structural types. Type A capitate glandular trichomes (Figure 12) consisted of a basal cell, a short unicellular stalk and a rather large secretory head made up of one cell with a cuticle. Type B (Figure 13) consisted of a basal cell, a unicellular stalk, a thin neck cell and a small secretory head made of one cell with a cuticle. Type $C$ (Figure 14) consisted of a basal cell, a relatively short bicellular stalk and a small secretory head consisting of one cell with a cuticle.

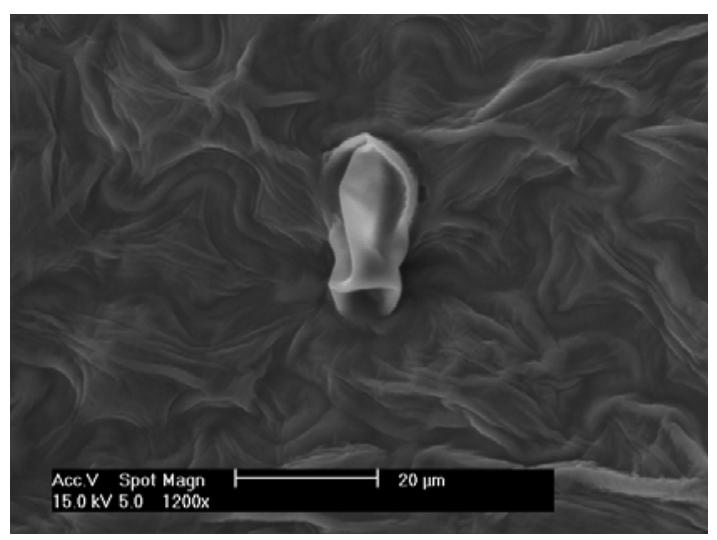

Fig. 12. Type A capitate glandular trichome: M. × gracilis (Hadžići, Sarajevo)

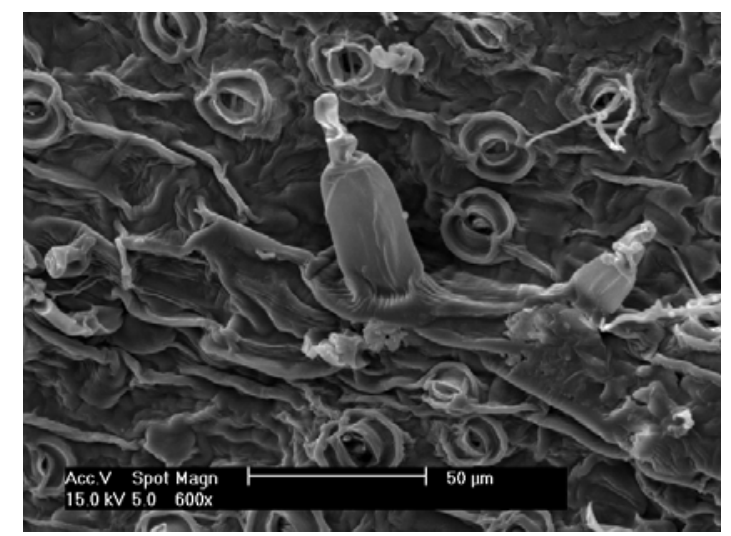

Fig. 13. Type B capitate glandular trichome: M. spicata (Maoča) 


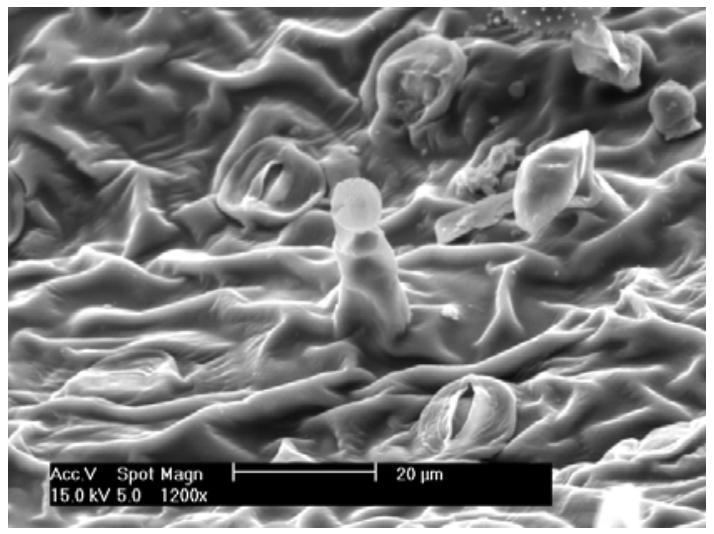

Fig. 14. Type C capitate glandular trichome: M. spicata (Bratislava)

The chemical composition of essential oils of the collected Mentha accessions was analysed by means of GC-MS. The GS separated compounds were identified from the recorded mass spectra by comparison with the mass spectra from the GS library. In total more than 60 different containing compounds were identified. However, according to the mentioned criteria and reasoning, these substances were reduced to 16 compounds: octanol, carvone, elemol, linalool, menthol, pulegone, terpinene, germacrene $D$, piperitone, $\beta$-pinene, trans-sabinene hydrate, 1,8-cineole, myrcene, viridiflorol, limonene. The composition of each mint in these essential oils is graphically visualized in Figure 21. Quantitative values are given in Table 5. This data, which represent the main compounds in essential oils, were finally used in the different cluster analyses.

The cluster analysis based on morphological characters (Figure 15) grouped the studied accessions according to taxonomy (except $M$. spicata), i.e. distinguished distinct groups of accessions which could be related to described and accepted taxa. These taxa were further joined into five major clusters or branches: $M . \times$ gracilis (Sarajevo, Banovići), M. $\times$ villosa (Travnik, Maoča, Banovići) created the first group; M. aquatica (Modra), M. arvensis (Revište), M. × gentilis (Banovići, Maoča, Treštenica, Crnjevo, Seona) made up the second group; M. longifolia ssp. Iongifolia (Bistričak, Tešanj, Maoča, Tuzla, Smetovi, Bratislava), M. longifolia ssp. lavanduliodora (Maoča, Bratislava), M. longifolia ssp. typhoides (Zenica), M. × verticillata (Bistričak) were joined in the third group; $M . \times$ piperita var. lavaduliodora (Maoča), M. rotundifolia (Maoča), M. pulegium (Maoča, Bistričak) created the fourth group, and the fifth group consisted of $M$. × piperita cv. 'Perpeta' (Bratislava), M. spicata (Crnjevo, Bratislava, Maoča), M. spicata var. crispa (Bratislava), $M$. $\times$ villosa cv. 'Snežna' (Bratislava), and M. × villosa (Bratislava). 


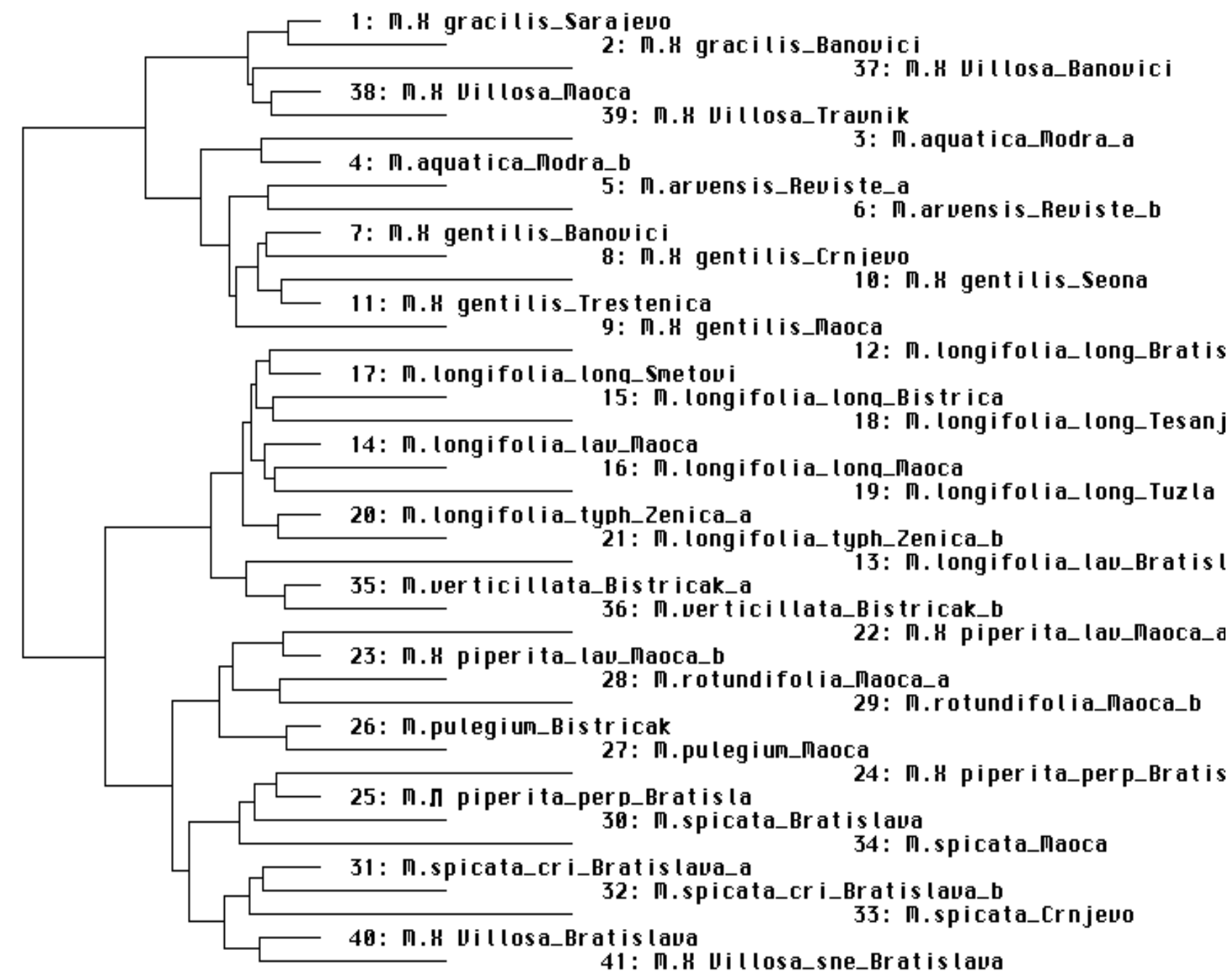

Fig. 15. Cluster analysis of cases (Ward method) based on morphological data

The cluster analysis based on anatomical characters (hair density, type of the capitate glandular trichomes, presence of the dendroid hairs and width of the peltate and capitate glandular trichomes) is shown in Figure 16. In this analysis the studied accessions were like in the morphology-based clustering mostly grouped according to taxonomy (except $M$. spicata) but were joined at a higher hierarchical level into groups different from that of the morphological analysis. In detail the following five taxonomic clusters were obtained: $M . \times$ gracilis (Sarajevo, Banovići), M.× verticillata (Bistričak), and M. pulegium (Maoča, Bistričak); M. aquatica (Modra), M. × piperita var. lavaduliodora (Maoča), M. arvensis (Revište), and M. × piperita cv. 'Perpeta' (Bratislava); M. × gentilis (Banovići, Maoča, Treštenica, Crnjevo, Seona), and M. spicata (Bratislava, Crnjevo, Maoča); M. longifolia ssp. Iongifolia (Bistričak, Tešanj, Maoča, Tuzla, Smetovi, Bratislava), M. longifolia ssp. typhoides (Zenica), and M. longifolia ssp. lavanduliodora (Maoča, Bratislava); and M. × villosa (Travnik, Maoča, Bratislava, Banovići), M. × villosa cv. 'Snežna' (Bratislava), M. spicata var. crispa (Bratislava), and Mentha rotundifolia (Maoča). 


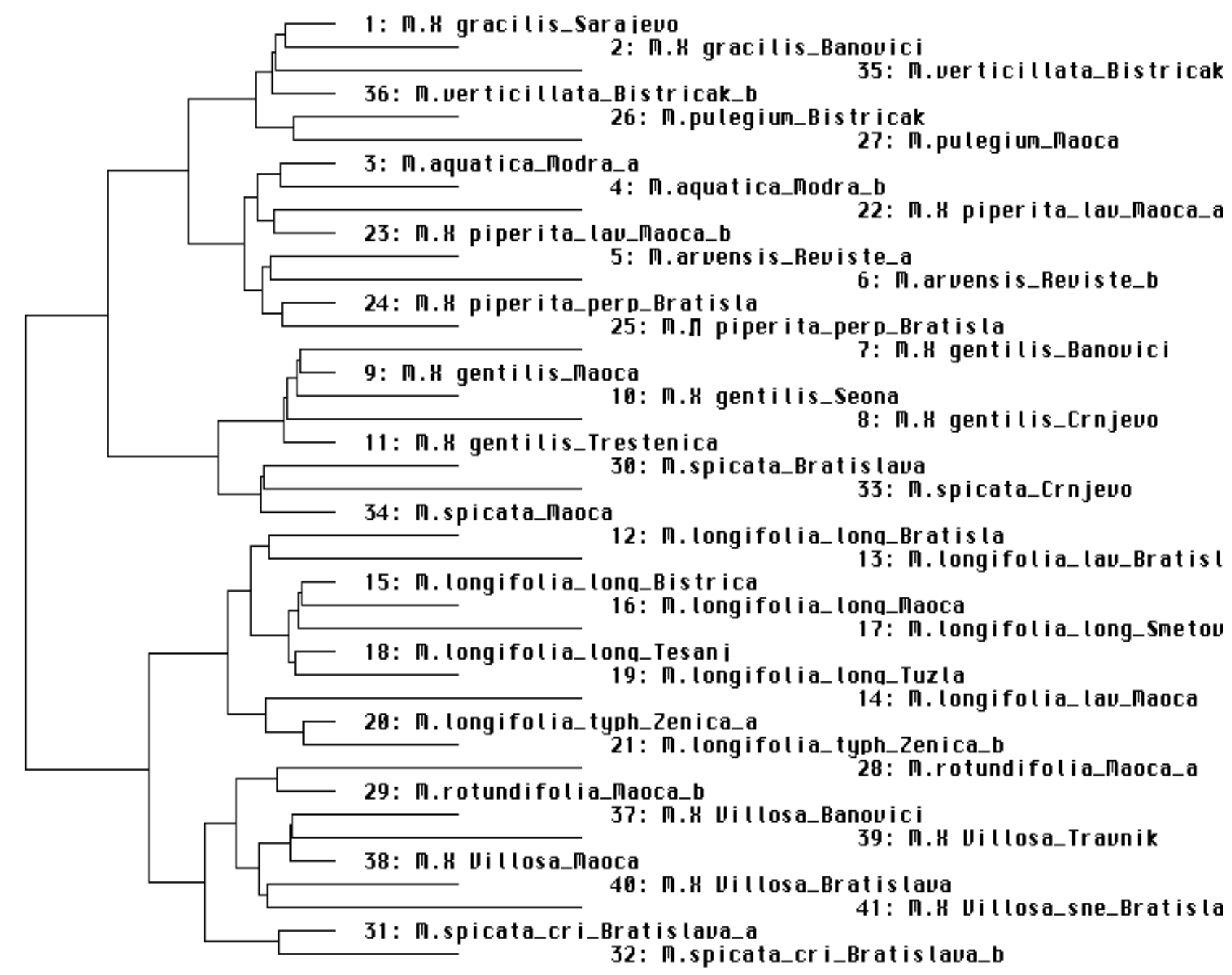

Fig. 16. Cluster analysis of cases (Ward method) based on anatomical characters

The gathered phytochemical data were used to create the third cluster analysis. Like mentioned this analysis was performed in two variants:

- Based on 25 standardized compounds with a relative peak area of at least $15 \%$ (in the standardized raw data!) each (Figure 17).

- Compounds pooled into groups according to the mentioned pathways (Table 4). These groups are presented in capital letters (Figure 18). 


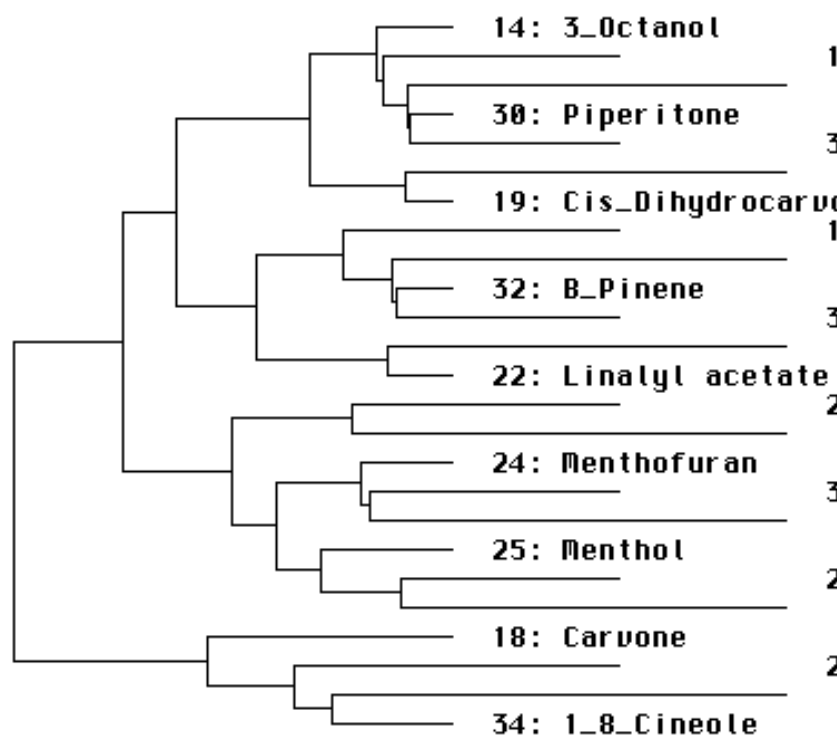

17: Carvacrol

27: G_Terpinene

33: Trans_Sabinene hudrate

16: Dihydr ocar veol

15: 3_octanone

28: Terpineol

35: Myrcene

23: Is omen thone

20: Elemol

26: Pulegone

36: Uer idif Lorol

38: Limonene

29: Germacrene_D

37: B_Caryophy I lene

21: Linalool

31: Piperitone onide

Fig. 17. Cluster analysis of (Ward method) 25 phytochemical compounds

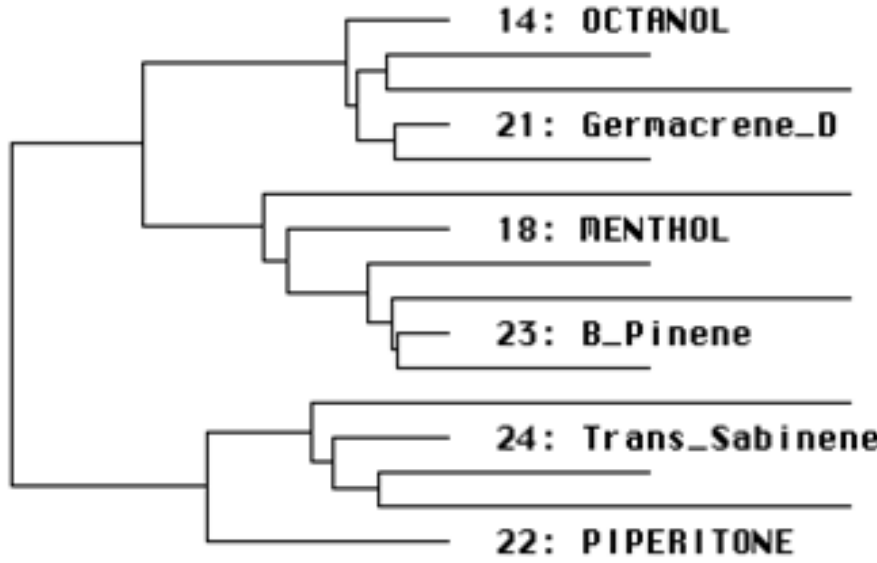

16: Elemol

27: Uer idiflorol

28: B_Caryophy I lene

17: LINALOOL

19: Pulegone

20: TERPINENE

26: Dyrcene

hudrate
25: 1_8_Cineole

\section{5: CARUONE}

29: Limonene

Fig. 18. Cluster analysis of (Ward method) 16 phytochemical compounds or groups of compounds

A cluster analysis of cases (i.e. accessions) based on the same chemical data used in the cluster analyses of variables (Figure 18) is presented in Figure 19. In contrast to the anatomy-based and morphology-based analyses only some of the studied accessions were grouped according to taxonomy. In particular, M. spicata and M. longifolia were found at different positions in the dendrogram. This result indicates a high amount of sharing of chemical compounds among the studied species. Thus, the investigated species mostly could not be distinguished on the basis of single compounds (e.g., M. spicata, M. $\times$ villosa, M. $\times$ gracilis, and $M . \times$ gentilis all shared carvone as main containing compound) by the cluster analysis. It was also impossible to discriminate all species when all compounds recognized by the GC analyses were considered. However, still, there are examples of essential oils like pulegone which were specific to single taxa, i.e. M. pulegium. 
Consequently, essential oil composition alone was not fully reliable to differentiate species and hybrids of the genus Mentha L. The taxa were clustered at the higher hierarchical level into the following five groups: M. × gracilis (Sarajevo, Banovići), M. spicata (Crnjevo, Maoča), M. spicata var. crispa (Bratislava), M. × villosa (Travnik, Maoča, Banovići, Bratislava), and M. × villosa cv. 'Snežna' (Bratislava); M. × gentilis (Banovići, Maoča, Treštenica, Crnjevo, Seona); M. aquatica (Modra), M. × piperita cv. 'Perpeta' (Bratislava), M. longifolia ssp. longifolia (Bratislava), and M. pulegium (Maoča, Bistričak); M. arvensis (Revište), M.× verticillata (Bistričak), M. rotundifolia (Maoča), M. spicata (Bratislava), M. longifolia ssp. typhoides (Zenica), M. longifolia ssp. lavanduliodora (Maoča, Bratislava), and M. × piperita var. lavaduliodora (Maoča); and M. longifolia ssp. longifolia (Bistričak, Tešanj, Maoča, Tuzla, Smetovi).

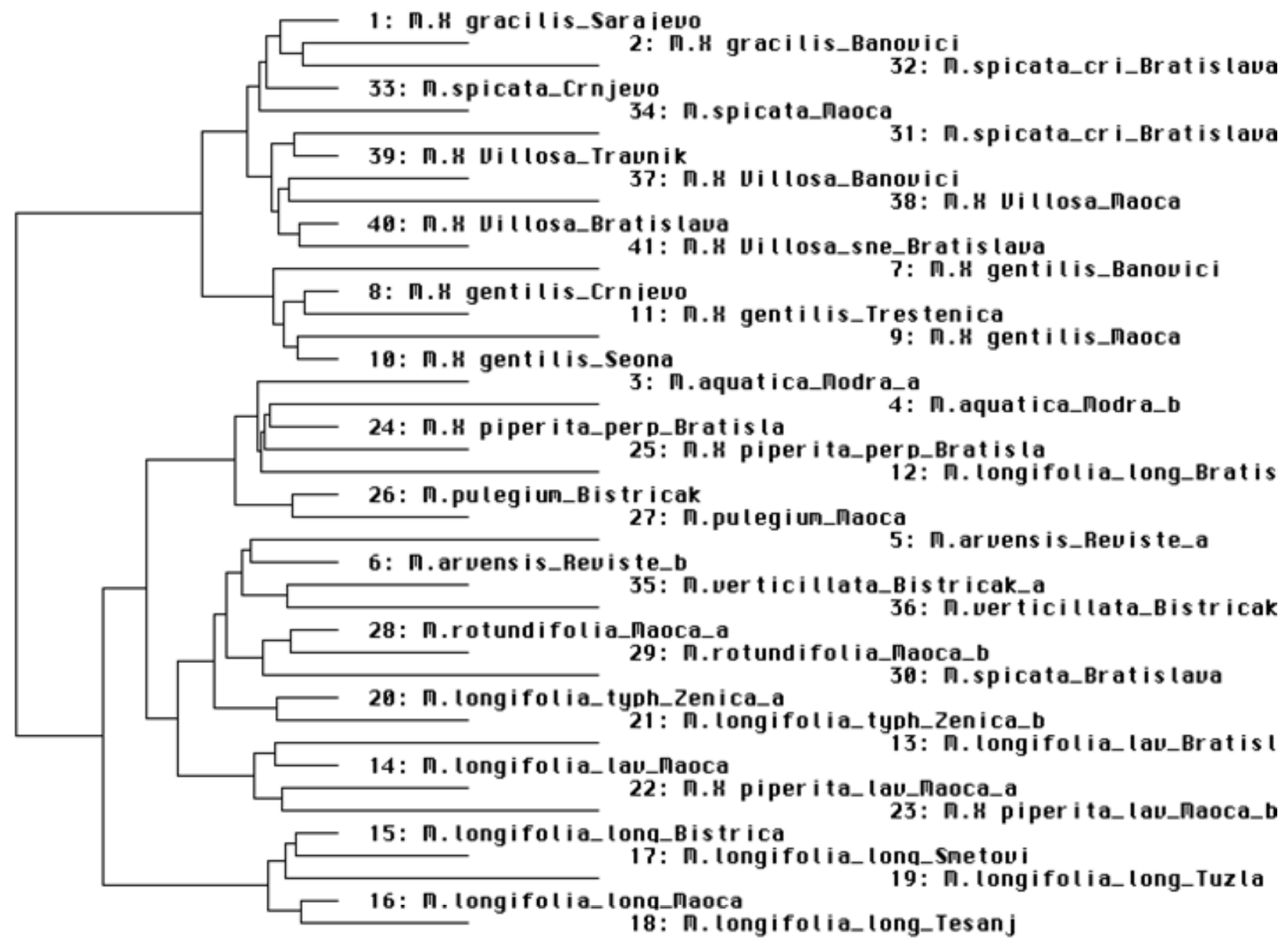

Fig. 19. Cluster analysis of cases (Ward method) using phytochemical data (16 compounds)

An additional hypothesis on the relationships among taxa was obtained in a fourth cluster analysis based on the combined morphological, anatomical and chemical data (Figure 20). 


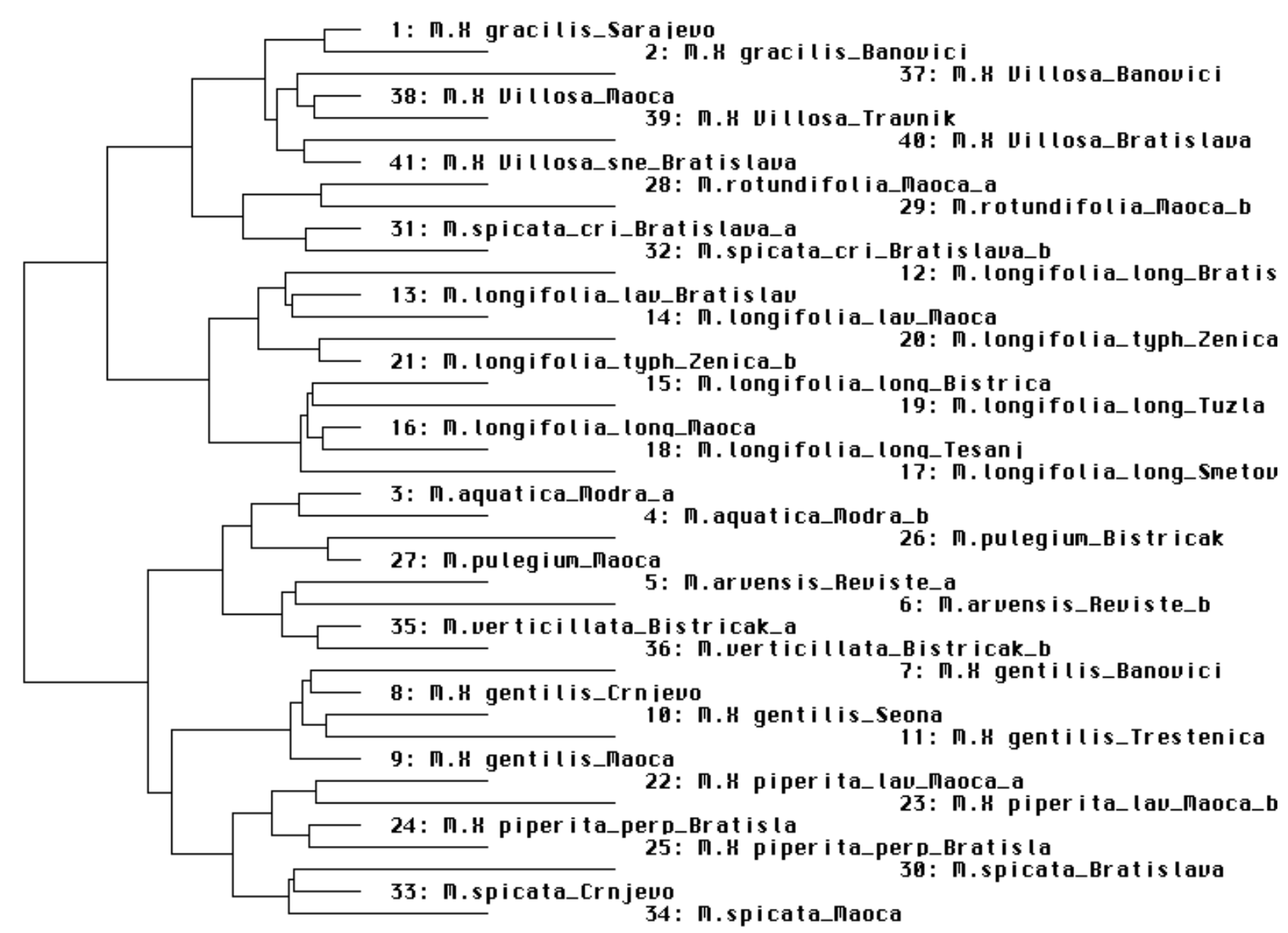

Fig. 20. Cluster analysis of cases (Ward method) based on the combined morphological, anatomical and chemical data.

The dendrograms constructed from the morphological, anatomical, and combined chemical data sets (Figure 15, 16, 19) differed from each other in the suggested relations between the investigated species. Obviously these individual data sets did not equivocally reflect the true evolutionary and phylogenetic relationships among mints, a result which fulfils expectations given the high amount of hybridization reported for Mentha. However, our results were in accordance with the DNA-based studies of Gobert et al. (2006) which demonstrated that mint species can be in most cases genetically clearly distinguished [5]. This view is supported by our data as the separate anatomical and morphological analyses each found consistently coherent groups of accessions, a criterion for the definition of taxa. However, the chemistry showed limited association only with the taxonomy of mints. 
The clusters of accessions observed with the different data sets could be referred to described taxa, both main species and hybrid species. Figure 21 provides an overview of the observed states for all 29 analyzed characters for the studied populations and taxa, respectively. The diagram is based on population means and their values are proportional to the area size of the shown squares. All parameters are standardized to the $0-100$ interval, where the smallest dots represent 0 and the biggest squares 100 . Although most of the observed traits were not specific to a particular species, species can be characterized by unique combinations of particular characters. This is seen from visually dense or loose blocks of squares and dots, respectively, which show the association of the different taxa with particular character traits. Table 5 provides the same but unsorted data. Among the observed and examined characters the inflorescence type, dentation of the leaf margin, hair density, the type of capitate glandular hairs and the main containing compound in essential oil appear to be the most useful ones for the characterization and discrimination of mint species. Particularly, taxa could be defined by the combination of anatomic, morphometric, and phytochemical data. By this approach, we could not only distinguish species but also subspecies and varieties. The discriminative ability of these analyses potentially still may be improved by further botanical or chemical examinations as only a selection of available characters could be included in our study (e.g., flavonoids aglycons or glycosides and phenolics acids).

As seen from the graphical visualization of observed characters states (Figure 21), M. $\times$ gracilis, $M$. $\times$ villosa and $M$. spicata var. crispa are phenetically closely related. These taxa have similar morphological and anatomical features and carvone as the major compound in essential oil. As mentioned before, $M . \times$ gentilis was considered synonym to $M . \times$ gracilis [1]. However, in our study $M . \times$ gentilis appeared to be another hybrid related to $M$. spicata ssp. spicata. Multivariate data analysis also supported the parentage of $M . \times$ verticillata as hybrid between $M$. aquatica and $M$. arvensis and the parentage of hybrid $M$. $\times$ piperita (M. aquatica $\times$ M. spicata), both of which combine anatomical, morphological and chemical markers typical of both parents.

The position of $M$. pulegium outside of section Mentha as a representative of section Pulegium, furthermore, was in agreement by the observation of particular high numbers of characters discriminating this species (e.g., leaf form, type of denticulation, main compound of essential oil). 

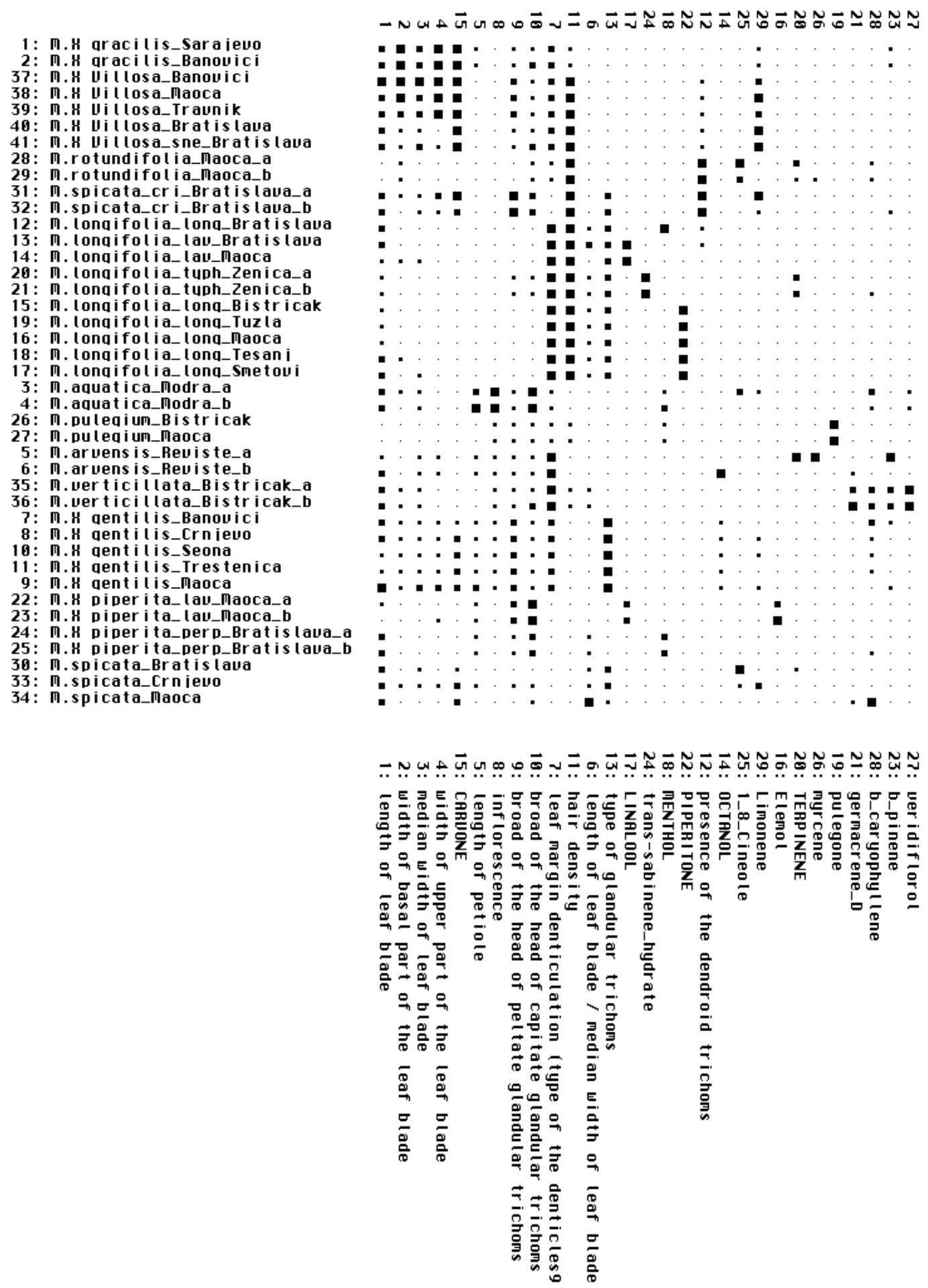

Fig. 21. Graphical visualization of the states of 29 morphological, anatomical and chemical characters as observed in the 33 studied mint populations. Cases and characters are ordered according to the cluster analysis of the combined data (Figure 20). The measured values (populations means) are proportional to the area of the squares. All values are standardized to the 0-100 interval, where the smallest dots represent 0 and the biggest squares 100 . 
Tab. 5. Anatomical and morphological properties of the studied taxa of genus Mentha

\begin{tabular}{|c|c|c|c|c|c|c|c|c|c|c|c|c|c|}
\hline Mentha sp. & 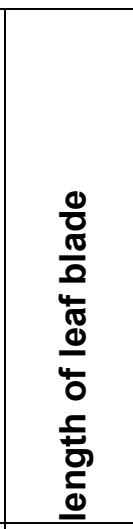 & 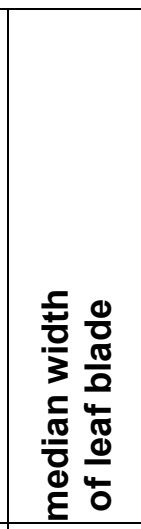 & 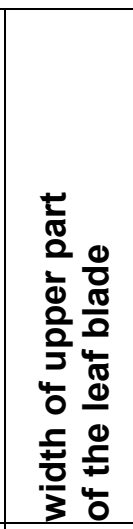 & 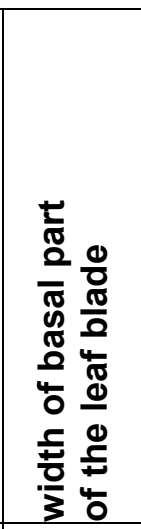 & 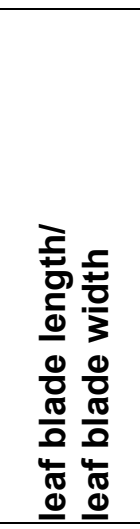 & 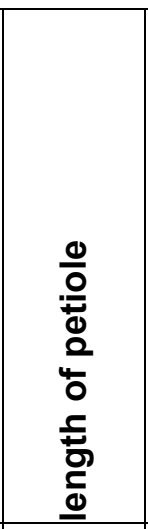 & 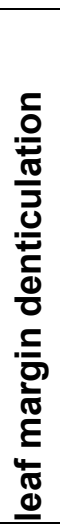 & 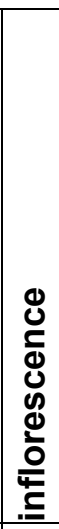 & 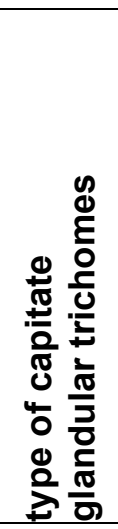 & 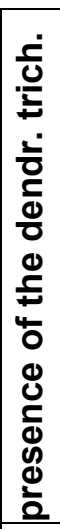 & 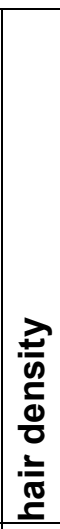 & 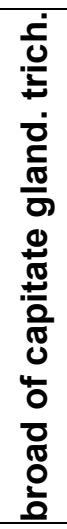 & 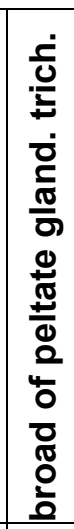 \\
\hline M. aquatica & $3,4-5,0$ & $1,6-2,5$ & $0,5-0,7$ & $1,0-1,6$ & $1,8-2,1$ & $1,3-1,7$ & $\mathrm{D}$ & $A$ & A & $A$ & $A$ & 23 & 67 \\
\hline M. spicata & $\begin{array}{l}5,3-5,4 \\
4,7-4,8 \\
4,5-6,0 \\
\end{array}$ & $\begin{array}{c}1 \\
1,9 \\
1,4-2,0\end{array}$ & $\begin{array}{c}0,4-0,5 \\
0,8 \\
0,3-0,6\end{array}$ & $\begin{array}{c}0,7 \\
1,5-1,6 \\
0,4-0,8 \\
\end{array}$ & $\begin{array}{c}5,3-5,4 \\
2,5 \\
2,9-3,3 \\
\end{array}$ & $\begin{array}{c}0,6-0,7 \\
0 \\
0,1-0,2 \\
\end{array}$ & $\begin{array}{l}C \\
C \\
C\end{array}$ & $\begin{array}{l}\text { B } \\
\text { B } \\
\text { B }\end{array}$ & $\begin{array}{c}A, B, C \\
A, C \\
A, C\end{array}$ & $\begin{array}{l}A \\
A \\
A\end{array}$ & $\begin{array}{l}A \\
A \\
A\end{array}$ & $\begin{array}{l}18 \\
17 \\
16 \\
\end{array}$ & \begin{tabular}{|l|}
64 \\
73 \\
63 \\
\end{tabular} \\
\hline $\begin{array}{l}\text { M. spicata } \\
\text { var. crispa }\end{array}$ & $4,0-5,5$ & $2,2-3,0$ & $0,6-1,7$ & $1,0-1,9$ & $1,4-2,1$ & 0 & C & B & $A, C$ & C & C & 20 & 86 \\
\hline M. arvensis & $3,2-4,7$ & $1,8-2,2$ & $0,7-1,0$ & $0,6-1,0$ & $1,8-2,4$ & $0,3-0,6$ & $\mathrm{C}$ & C & A & A & A & 19 & 67 \\
\hline $\begin{array}{l}\text { M. longifolia } \\
\text { ssp. longifolia }\end{array}$ & $\begin{array}{l}4,0-4,3 \\
4,3-4,4 \\
4,0-4,3 \\
3,5-3,7 \\
4,9-5,1 \\
4,0-5,2\end{array}$ & $\begin{array}{l}1,2-1,4 \\
1,4-1,6 \\
1,5-1,7 \\
1,4-1,5 \\
1,9-2,0 \\
1,3-1,9\end{array}$ & $\begin{array}{c}0,4-0,5 \\
0,5 \\
0,4-0,5 \\
0,4-0,5 \\
0,5-0,7 \\
0,5-0,8\end{array}$ & $\begin{array}{l}0,8-1,0 \\
1,1-1,3 \\
1,0-1,2 \\
1,0-1,1 \\
1,0-1,1 \\
0,7-0,9\end{array}$ & $\begin{array}{l}3,0-3,3 \\
2,8-3,1 \\
2,5-2,7 \\
2,4-2,5 \\
2,5-2,6 \\
2,7-3,3\end{array}$ & $\begin{array}{l}0,1 \\
0,1 \\
0,1 \\
0,1 \\
0,1 \\
0,1\end{array}$ & $\begin{array}{l}B \\
B \\
B \\
B \\
B \\
B\end{array}$ & $\begin{array}{l}\text { B } \\
B \\
B \\
B \\
B \\
B\end{array}$ & $\begin{array}{l}A, C \\
A, C \\
A, C \\
A, C \\
A, C \\
A, C\end{array}$ & $\begin{array}{l}A \\
A \\
A \\
A \\
A \\
B\end{array}$ & $\begin{array}{l}A \\
A \\
A \\
A \\
A \\
B\end{array}$ & $\begin{array}{l}15 \\
15 \\
15 \\
15 \\
15 \\
15\end{array}$ & $\begin{array}{l}57 \\
57 \\
57 \\
57 \\
57 \\
57\end{array}$ \\
\hline $\begin{array}{l}\text { M. Iongifolia var. } \\
\text { lavanduliodora }\end{array}$ & $\begin{array}{l}4,0-4,1 \\
4,9-6,3 \\
\end{array}$ & $\begin{array}{l}1,9-2,0 \\
1,1-1,4\end{array}$ & $\begin{array}{l}0,7-0,8 \\
0,5-0,7 \\
\end{array}$ & $\begin{array}{l}1,0-1,2 \\
0,8-1,1 \\
\end{array}$ & $\begin{array}{l}2,2-2,3 \\
4,1-4,8 \\
\end{array}$ & $\begin{array}{c}0,1 \\
0,0-0,2 \\
\end{array}$ & $\begin{array}{l}\mathrm{B} \\
\mathrm{B}\end{array}$ & $\begin{array}{l}B \\
B\end{array}$ & $\begin{array}{l}A, C \\
A, C\end{array}$ & $\begin{array}{l}\text { A } \\
A\end{array}$ & $\begin{array}{l}\mathrm{A} \\
\mathrm{B}\end{array}$ & $\begin{array}{l}17 \\
16 \\
\end{array}$ & $\begin{array}{l}65 \\
60 \\
\end{array}$ \\
\hline $\begin{array}{l}\text { M. longifolia } \\
\text { ssp. typhoides }\end{array}$ & $2,9-3,0$ & $1,0-1,2$ & $0,4-0,5$ & $1,0-0,8$ & $2,5-2,9$ & 0,1 & B & B & $A, C$ & A & A & 18 & 70 \\
\hline M. rotundifolia & $1,8-2,0$ & $1,4-1,6$ & $0,4-0,5$ & $1,3-1,4$ & 1,3 & 0 & D & B & A & $\mathrm{C}$ & C & 17 & 59 \\
\hline $\begin{array}{l}\text { M. } \times \text { piperita } \\
\text { cv. 'Perpeta' }\end{array}$ & $4,0-4,8$ & $1,2-1,6$ & $0,4-0,7$ & $0,6-1,0$ & $3,0-3,3$ & $0,5-0,7$ & C & B & A & A & A & 20 & 69 \\
\hline $\begin{array}{l}\text { M. } \times \text { piperita var. } \\
\text { lavanduliodora }\end{array}$ & $2,6-3,1$ & $1,2-1,4$ & $0,5-0,7$ & 0,9 & $2,2-2,3$ & $0,5-0,6$ & C & B & A & A & A & 22 & 76 \\
\hline M. $\times$ villosa & $\begin{array}{l}5,7-6,4 \\
4,7-5,0 \\
4,5-4,7 \\
4,1-5,5 \\
\end{array}$ & \begin{tabular}{|l|}
$3,8-4,2$ \\
$2,9-3,3$ \\
$3,5-3,6$ \\
$2,0-3,0$ \\
\end{tabular} & \begin{tabular}{|l}
$1,6-1,8$ \\
$1,5-1,6$ \\
$1,5-1,7$ \\
$0,4-1,0$ \\
\end{tabular} & \begin{tabular}{|l|}
$2,2-2,3$ \\
$2,2-2,3$ \\
$2,2-2,3$ \\
$1,2-2,0$ \\
\end{tabular} & $\begin{array}{c}1,3-1,5 \\
1,5-1,7 \\
1,3 \\
1,8-2,3 \\
\end{array}$ & $\begin{array}{l}0 \\
0 \\
0 \\
0 \\
\end{array}$ & $\begin{array}{l}A \\
A \\
A \\
A\end{array}$ & $\begin{array}{l}B \\
B \\
B \\
B \\
\end{array}$ & $\begin{array}{l}A \\
A \\
A \\
A\end{array}$ & \begin{tabular}{|l}
$B$ \\
$B$ \\
$A$ \\
$B$ \\
\end{tabular} & $\begin{array}{l}B \\
B \\
A \\
B \\
\end{array}$ & $\begin{array}{l}17 \\
17 \\
17 \\
18 \\
\end{array}$ & $\begin{array}{l}76 \\
76 \\
76 \\
71 \\
\end{array}$ \\
\hline $\begin{array}{l}\text { M. × villosa cv. } \\
\text { 'Snežna' }\end{array}$ & $4,8-6,2$ & $2,4-3,8$ & $0,8-1,1$ & $1,0-2,0$ & $1,6-2,1$ & $0,1-0,2$ & A & B & A & B & B & 20 & 72 \\
\hline M. $\times$ verticillata & $5,6-5,7$ & $1,8-1,9$ & 0,5 & $1,2-1,3$ & 0,2 & 0,2 & $B$ & $\mathrm{C}$ & A & A & A & 19 & 57 \\
\hline M. $\times$ gentilis & $\begin{array}{l}4,6-4,8 \\
6,5-6,6 \\
3,8-4,0 \\
4,4-4,5 \\
4,0-4,2 \\
\end{array}$ & $\begin{array}{l}2,1-2,3 \\
3,3-3,5 \\
2,3-2,4 \\
1,8-1,9 \\
2,1-2,3 \\
\end{array}$ & $\begin{array}{l}1,0-1,1 \\
1,1-1,3 \\
1,0-1,1 \\
0,8-1,0 \\
0,9-1,0\end{array}$ & $\begin{array}{c}1,3-1,4 \\
1,6-1,7 \\
1,3 \\
1,3 \\
1,3-1,5\end{array}$ & $\begin{array}{c}0,5-0,6 \\
0,9-1 \\
0,5-0,6 \\
0,5-0,6 \\
0,6\end{array}$ & $\begin{array}{c}0,5-0,6 \\
0,9-1,0 \\
0,5-0,6 \\
0,5-0,6 \\
0,6\end{array}$ & $\begin{array}{l}A \\
A \\
A \\
A \\
A\end{array}$ & $\begin{array}{l}C \\
C \\
C \\
C \\
C\end{array}$ & $\begin{array}{l}A, B \\
A, B \\
A, B \\
A, B \\
A, B\end{array}$ & $\begin{array}{l}A \\
A \\
A \\
A \\
A\end{array}$ & $\begin{array}{l}A \\
A \\
A \\
A \\
A\end{array}$ & $\begin{array}{l}19 \\
19 \\
19 \\
19 \\
19\end{array}$ & $\begin{array}{l}79 \\
79 \\
79 \\
79 \\
79 \\
\end{array}$ \\
\hline M. $\times$ gracilis & $\begin{array}{l}5,6-5,7 \\
5,4-5,7\end{array}$ & $\begin{array}{c}3,5-3,6 \\
3,5\end{array}$ & $\begin{array}{l}1,6-1,7 \\
1,6-1,7\end{array}$ & $\begin{array}{c}0,7 \\
1,5-1,6\end{array}$ & $\begin{array}{c}0,5-0,6 \\
0,5\end{array}$ & $\begin{array}{c}0,5-0,6 \\
0,5\end{array}$ & $\begin{array}{l}A \\
A\end{array}$ & $\begin{array}{l}\text { B } \\
B\end{array}$ & $\begin{array}{l}A \\
A\end{array}$ & $\begin{array}{l}B \\
B\end{array}$ & $\begin{array}{l}\mathrm{B} \\
\mathrm{B}\end{array}$ & $\begin{array}{l}19 \\
19\end{array}$ & $\begin{array}{l}68 \\
68\end{array}$ \\
\hline $\begin{array}{l}\text { Mentha } \\
\text { pulegium }\end{array}$ & $\begin{array}{l}1,0-1,5 \\
1,2-1,5\end{array}$ & \begin{tabular}{|l|}
$0,5-0,8$ \\
$0,6-0,8$
\end{tabular} & $\begin{array}{l}0,5-0,6 \\
0,5-0,6\end{array}$ & $\begin{array}{l}0,3-0,5 \\
0,5-0,6\end{array}$ & $\begin{array}{l}0,3-0,5 \\
0,3-0,4\end{array}$ & \begin{tabular}{|l|}
$0,3-0,5$ \\
$0,3-0,4$
\end{tabular} & $\begin{array}{l}\mathrm{D} \\
\mathrm{D}\end{array}$ & $\begin{array}{l}C \\
C\end{array}$ & $\begin{array}{l}A \\
A\end{array}$ & $\begin{array}{l}\text { A } \\
\text { A }\end{array}$ & $\begin{array}{l}\mathrm{A} \\
\mathrm{A}\end{array}$ & $\begin{array}{l}17 \\
17\end{array}$ & \begin{tabular}{|l|}
67 \\
67
\end{tabular} \\
\hline
\end{tabular}


Tab. 5. (Cont.)

\begin{tabular}{|c|c|c|c|c|c|c|c|c|c|c|c|c|c|c|c|c|}
\hline Mentha sp. & $\begin{array}{l}\overrightarrow{1} \\
\mathbf{0} \\
\mathbf{z} \\
\stackrel{5}{\circ} \\
0 \\
0\end{array}$ & 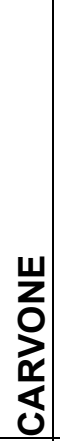 & $\begin{array}{c}\overline{\mathbf{g}} \\
\frac{\mathbf{c}}{\mathbf{\Phi}}\end{array}$ & $\begin{array}{l}\overrightarrow{1} \\
0 \\
0 \\
\frac{1}{5} \\
\underline{z}\end{array}$ & 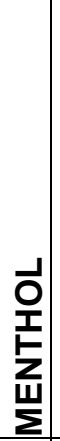 & 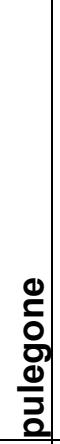 & 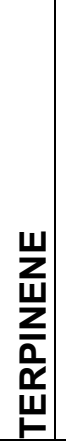 & 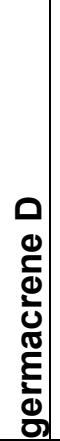 & 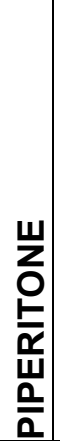 & 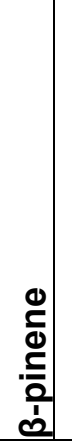 & 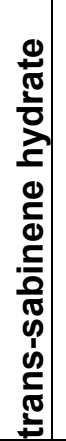 & 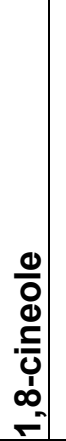 & 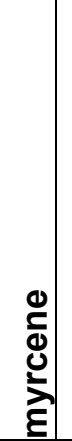 & $\begin{array}{l}\overline{0} \\
\overline{0} \\
\overline{\frac{0}{0}} \\
\overline{0} \\
\overline{\mathbf{0}}\end{array}$ & 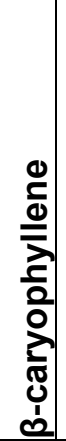 & 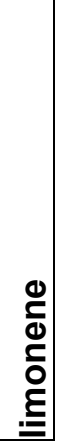 \\
\hline M. aquatica & & & & & $\mathrm{x}$ & & & & & & & & & & & \\
\hline M. spicata & & $\begin{array}{l}x \\
x \\
x\end{array}$ & & & & & & & & & & & & & & \\
\hline $\begin{array}{l}\text { M. spicata } \\
\text { var. crispa }\end{array}$ & & $x$ & & & & & & & & & & & & & & \\
\hline M. arvensis & & & & & & & & & $x$ & & & & $x$ & & & \\
\hline $\begin{array}{l}\text { M. longifolia } \\
\text { ssp. longifolia }\end{array}$ & & & & & $x$ & & & & $\begin{array}{l}x \\
x \\
x \\
x \\
x\end{array}$ & & & & & & & \\
\hline $\begin{array}{l}\text { M. longifolia var. } \\
\text { lavanduliodora }\end{array}$ & & & & $\begin{array}{l}x \\
x\end{array}$ & & & & & & & & & & & & \\
\hline $\begin{array}{l}\text { M. longifolia } \\
\text { ssp. typhoides }\end{array}$ & & & & & & & & & & & $x$ & & & & & \\
\hline M. rotundifolia & & & & & & & & & & & & $x$ & & & & \\
\hline $\begin{array}{l}\text { M. × piperita } \\
\text { cv. 'Perpeta' }\end{array}$ & & & & & $x$ & & & & & & & & & & & \\
\hline $\begin{array}{l}\text { M. × piperita var. } \\
\text { lavanduliodora }\end{array}$ & & & & $x$ & & & & & & & & & & & & \\
\hline M. $\times$ villosa & & $\begin{array}{l}x \\
x \\
x \\
x\end{array}$ & & & & & & & & & & & & & & \\
\hline $\begin{array}{l}\text { M. × villosa cv. } \\
\text { 'Snežna' }\end{array}$ & & $x$ & & & & & & & & & & & & & & \\
\hline M. $\times$ verticillata & & & & & & & & $\mathrm{x}$ & & & & & & & & \\
\hline M. $\times$ gentilis & & $\begin{array}{l}x \\
x \\
x \\
x \\
x\end{array}$ & & & & & & & & & & & & & & \\
\hline M. $\times$ gracilis & & $\begin{array}{l}x \\
x\end{array}$ & & & & & & & & & & & & & & \\
\hline $\begin{array}{l}\text { Mentha } \\
\text { pulegium }\end{array}$ & & & & & & $\begin{array}{l}x \\
x\end{array}$ & & & & & & & & & & \\
\hline
\end{tabular}




\section{Acknowledgements}

We express our deep gratitude to Dr. Elena Popovic for the help with GC/MS analyses. Silvia Fialova would also like to thank the grant UK/10/2008 and grant UK/23/2009 for financial support.

\section{Authors' Statement}

\section{Competing Interests}

The authors declare no conflict of interest.

\section{References}

[1] McKay DL, Blumberg JB.

A review of the bioactivity and potential health benefits of peppermint tea (Mentha piperita L.).

Phytother Res. 2006; 20: 619-633.

doi:10.1002/ptr.1936

[2] Tucker AO, Harley RM, Fairbrothers DE.

The Linnaean types of Mentha (Lamiaceae).

Taxon. 1980; 29: 233-255.

doi: $10.2307 / 1220285$

[3] Tucker AO, Naczi RFC.

Mentha: An Overview of Its Classification and Relationships

In: Mint. The genus Mentha. Medical and Aromatic Plants - Industrial Profiles.

Volume 44, Boca Raton, London, New York: CRC Press, Taylor \& Francis Group. 2007: 3-39.

[4] Harley RM, Brighton CA.

Chromosome numbers in the genus Mentha $\mathrm{L}$.

Bot J Linn Soc. 1977; 74: 71-96.

doi:10.1111/j.1095-8339.1977.tb01168.x

[5] Gobert V, Moja S, Taberlet P, Wink M.

Heterogenity of three Molecular data partition phylogenies of mints related to M. × piperita (Mentha; Lamiaceae).

Plant Biol. 2006; 8: 470-485.

doi:10.1055/s-2006-924043.

[6] Briquet J.

Preslia. Mentha.

In: Die Natürlichen Pflanzenfamilien. Volume3a and 4.

Leipzig: Engler A and Prantl K, Eds., Wilhelm Engelmann, 1896: 317-324.

[7] Schalk M, Croteau R.

A single amino acid substitution (F363I) converts the regiochemistry of the spearmint (-)-limonene hydroxylase from C6- to a C3-hydroxylase.

Proc Natl Acad Sci U S A. 2000; 97: 11948-11953.

doi:10.1073/pnas.97.22.11948

[8] Lawrence BM.

Oil composition of other Mentha species and hybrids.

In: Mint. The genus Mentha. Medical and Aromatic Plants - Industrial Profiles.

Volume 44, Boca Raton, London, New York: CRC Press, Taylor \& Francis Group. 2007: 325-346.

[9] Topitz A.

Beiträge zur Kenntnis der Menthenflora von Mitteleuropa.

Beihefte zum Botanischen Centralblatt. 1913; 30: 138-264. 
[10] Malinvaud E.

Simple aperçu des hybrides dans le genere Mentha.

Bulletin de la Société Botanique de France. 1880; 27: 332-347.

[11] Hegi G.

DCXXXII. Méntha.

In: Illustrierte Flora von Mittel-Europa.

Volume 5, Vienna: A. Pichler's Witwe \& Sohn. 1928: 2335-2357.

[12] List PH, Hörhammer L.

Mentha.

In:Hagers Handbuch der Pharmazeutischen Praxis.

Volume 5, Berlin-Heidelberg-New York, Springer Verlag. 1976: 767-780.

[13] Celenk S, Tarimcilar G, Bicakci A, Kaynak G, Malyer H.

A palynological study of the genus Mentha L. (Lamiaceae).

Bot J Linn Soc. 2008; 157: 141-154.

doi:10.1111/j.1095-8339.2008.00789.x

[14] Šarić-Kundalić B, Fialová S, Saukel J, Olzant SM, Tekel'ová D, Grančai D.

Anatomical and Phytochemical Differentiation of Mentha species.

Sci Pharm. 2009; 77: 262.

doi:10.3797/scipharm.oephg.21.PO-63

[15] Dorman DHJ, Koşar M, Kahlos K, Holm Y, Hiltunen R.

Antioxidant properties and composition of aqueous extracts from Mentha species, hybrids, varieties and cultivars.

J Agric Food Chem. 2003; 51: 4563-4569.

doi:10.1021/jf034108k

[16] Rösch P, Kieffer W, Popp J.

Chemotaxonomy of Mints of genus Mentha by applying Raman spectroscopy.

Biopolymers. 2002; 67: 358-361.

doi:10.1002/bip.10099

[17] Gobert V, Moja S, Colson M, Taberlet P.

Hybridization in the section Mentha (Lamiaceae) inferred from AFLP markers.

Am J Bot. 2002; 89: 2017-2023.

doi:10.3732/ajb.89.12.2017

[18] Khanuja SPS, Shasany AK, Srivastava A, Kumar S.

Assessment of genetic relationships in Mentha species.

Euphytica. 2000; 111: 121-125.

doi:10.1023/A:1003829512956

[19] Bertová L.

Genus Mentha L.

In: Slovak Flora V/1 (in Slovak).

Slovak Academy of Sciences Bratislava, 1993: 375-396.

[20] Tutin TG, Heywood VH, Burges NA, Valentine DH, Walters SM, Webb DA. Mentha L.

In: Flora Europea. Volume 3.

Cambridge University Press, Cambrige. 1972: 183-186.

[21] Council of Europe.

Menthae piperitae folium.

In: European Pharmacopoeia $6^{\text {th }}$ Edition.

Strasbourg. 2007: 2638.

[22] Fischer MA, Ooswald K, Adler W.

Mentha.

Exkursionsflora für Österreich, Liechtenstein und Südtirol.

OÖ Landesmuseen. 2008; 798-800. 
[23] Rauchensteiner F, Nejati S, Werner I, GlasI S, Saukel J, Jurenitsch J, Kubelka W. Determination of the Achillea millefolium group and Achillea crithmifolia by morphological and phytochemical methods. I. Characterisation of Central european taxa.

Sci Pharm. 2002; 70: 199-230.

[24] Fritz E, Ölzant SM, Länger R. Illicium verum Hook.f. and Illicium anisatum L.: Anatomical charactera and their value for differentiation.

Sci Pharm. 2008;76: 65-76.

doi:10.3797/scipharm.0802-03

[25] Ward JH.

Hierarchical grouping to optimize an objective function.

J Am Stat Assoc. 1963; 58: 236-244.

doi:10.2307/2282967

[26] Saukel, J.

New methods of computer-aided analysis in pharmacognosy.

Planta Med. 1988; 54: 568-.

doi:10.1055/s-2006-962572

[27] Saukel J, Langer R.

MOBCENTR: A nonhierarchical classification algorithm for exploratory data analysis (EDA).

Plant Syst Evol. 1989; 168: 87-94.

doi:10.1007/BF00936090

[28] Maffei M, Chialva F, Sacco T.

Glandular trichomes and essential oils in developing peppermint leaves. I. Variation of peltate trichome number and terpene distribution within leaves

New Phytol. 1989; 111: 707-716.

doi:10.1111/j.1469-8137.1989.tb02366.x 